\title{
Does Socially Responsible Investing Change Firm Behavior?
}

First Draft: December 2020

This Draft: August 2021*

\begin{abstract}
Socially responsible investment (SRI) funds are increasing in popularity. Yet, it is unclear if these funds improve corporate behavior. Using novel micro-level data, we find that SRI funds select firms with higher environmental and social standards: the firms they hold exhibit lower pollution, greater board diversity, higher employee satisfaction, and higher workplace safety. Yet, using an exogenous shock to SRI capital, we find no evidence that SRI funds improve firm behavior. The results suggest SRI funds invest in a portfolio consistent with the fund's objective, but they do not significantly improve corporate conduct.
\end{abstract}

Keywords: Corporate Social Responsibility (CSR), Environmental, Social, and Governance (ESG), Institutional Investors, Socially Responsible Investing (SRI)

JEL Classification Numbers: G12, G14

*We thank John Barrios, Matthias Breuer, Lauren Cohen, Mike Cooper, Shaun Davies, Alex Edmans, Fabrizio Ferri, Henry Friedman, Umit Gurun, Michael Halling, Mirko Heinle, Sehoon Kim, Karl Lins, John Matsusaka, Dhananjay Nanda, Yihui Pan, Enrichetta Ravina (discussant), Zacharias Sautner, Mitch Towner, Ed Van Wesep, and Tracy Wang for helpful comments. We also thank virtual seminar participants at Chapman University, Columbia University (Accounting), the Corporate Governance and Executive Compensation Research Series, Georgetown University, The Hong Kong University of Science and Technology, Singapore Management University, and Virginia Tech. We thank Glassdoor, Inc. (www.Glassdoor.com) and the Environmental Protection Agency for providing data and for helpful conversations. All errors are our own. (C)2020-2021. 


\section{Introduction}

Friedman (1970) popularized the view that corporate managers should work to maximize shareholder value. More recently, this view has been challenged. Bénabou and Tirole (2010) and Hart and Zingales (2017) argue that corporations should instead seek to maximize shareholder welfare and that socially responsible investment (SRI) funds should play a role in addressing environmental and social issues. ${ }^{1}$ While this debate remains unsettled, there is a related fundamental question that is also unanswered: do socially responsible investment funds change real-world behavior? Put differently, to understand whether SRI funds should play a larger role in society it is first necessary to understand whether these funds actually influence corporate behavior. In this paper, we use detailed micro-level data to provide some of the first empirical evidence on the real effects of socially responsible investing.

We assemble a novel set of outcome variables that measure whether SRI affects different firm stakeholders. ${ }^{2}$ Our outcome variables assess the relation between SRI, the environment, and the employee well-being. On the environmental dimension, we examine nine measures of pollution using data from the Environmental Protection Agency (EPA); on the social dimension, we examine nine measures of employee satisfaction using data from Glassdoor, Inc., two measures of workplace safety using data from the U.S. Department of Labor Occupational Safety and Health Administration (OSHA), and two measures of diversity on the board of directors using data from BoardEx and ISS. We find that SRI funds do select companies with

\footnotetext{
${ }^{1}$ SRI funds are mutual funds or exchange traded funds who have a stated objective regarding the environmental and/or social behavior of their portfolio firms.

${ }^{2}$ We do not examine third party environmental and social (E\&S) ratings, as a growing literature suggests they may be unreliable. Berg, Koelbel, and Rigobon (2019) document that E\&S ratings often differ significantly for the same firm across different rating agencies, and Cohen, Gurun, and Nguyen (2020) provide evidence that E\&S ratings may not accurately measure behavior. Moreover, Berg, Fabisik, and Sautner (2020) show that firms seem to modify their data ex-post, such that the rewritten data better matches the firm's ESG-related performance. Accordingly, we avoid this issue by focusing on outcome variables, instead of E\&S ratings. Yet, our conclusions are unchanged if we instead use E\&S ratings.
} 
better environmental and social conduct, but SRI funds do not improve the environmental or social behavior of their portfolio firms.

To date, it is unclear how the actions of SRI funds affect firm-level stakeholders. There are three main possibilities. First, SRI funds might not behave differently than non-SRI funds in their portfolio choices or the way in which they interact with firms (i.e., "greenwashing"). Second, SRI funds might select companies that focus on environmental and social issues, but not engage with them (i.e., a selection effect). ${ }^{3}$ Finally, SRI funds might actively work to improve the environmental and social behavior of the companies in their portfolio (i.e., a treatment effect). In fact, $66 \%$ of SRI funds have an explicit stated objective of improving the behavior of their portfolio companies through direct engagement (Forum for Sustainable and Responsible Investing (2021)).

Theoretically, it is unclear which effect should prevail. On the one hand, the cost of engaging with portfolio firms and changing their behavior is likely higher than the cost of pure portfolio selection based on observable E\&S performance; thus, funds may lack the incentive to engage (Davies \& Van Wesep, 2018; H. L. Friedman \& Heinle, 2020). Also, SRI funds might not have the expertise, resources or stewardship personnel to effectively engage with their portfolio firms (Bebchuk \& Tallarita, 2020). On the other hand, the recent increase in the size of SRI funds could make them more effective monitors through coordination with activists (Dimson, Karakaş, \& Li, 2015) or the threat of exit (Edmans, 2009; Edmans \&

\footnotetext{
${ }^{3}$ The selection effect could also generate a response by firms, as theory predicts that the threat of entry or exit by a fund can itself induce firms to change their behavior (Edmans, 2009; Edmans \& Manso, 2010). However, in Table A4 of the Appendix we show that SRI funds do not allocate more (or less) capital to firms that recently change their E\&S policies, suggesting this channel is not influential for E\&S issues.

${ }^{4}$ Many funds claim to improve firm behavior. For example, BlackRock's Investment Stewardship team claims to regularly engage with companies to understand how material environmental factors are considered from the perspective of risk and opportunity (BlackRock, 2020). Similarly, Domini Social Equity Fund (2021) claims to influence corporations through shareholder activism: "In pursuing our clients' sustainability objectives, we seek to influence the actions of corporations on a wide range of social, environmental and governance issues."
} 
Manso, 2010). In fact, a recent survey suggests that SRI funds do view engagement as a tool for addressing climate risks (Krueger, Sautner, \& Starks, 2020). ${ }^{5}$

Empirically, examining the impact of SRI is challenging because holdings by SRI funds may be endogenously related to firm characteristics. First, different firm policies attract different types of investors, making it difficult to determine if SRI funds change behavior at their portfolio companies or merely select companies that behave differently. Second, firm characteristics such as corporate governance may jointly affect ownership by SRI funds and responsible behavior (Dyck, Lins, Roth, Towner, \& Wagner, 2020). As a result, there is concern of both reverse causality and omitted variable bias in this setting. Accordingly, we develop a novel research design that uses exogenous variation in the amount of capital allocated to SRI funds to examine the impact of SRI funds.

Our research design exploits discontinuities in the assignment of Morningstar "star ratings" as an exogenous shock to fund capital. Morningstar is an investment research company that provides independent ratings of investment funds. Each period, Morningstar ranks the universe of investment funds using a proprietary algorithm that evaluates funds based on their risk-adjusted returns within an investment category. The best performing funds receive five stars, while the worst performing funds receive one star. These star ratings are widely used by investors, and they have been shown to strongly affect the amount of investor capital allocated to a given fund (Reuter \& Zitzewitz, 2021). Importantly, it is nearly impossible for funds to manipulate their rating each period, and the discontinuities in the "star rating" leads to sharp discontinuities in capital allocation. ${ }^{6}$

\footnotetext{
${ }^{5}$ Moreover, Chowdhry, Davies, and Waters (2019) show that impact investors can, theoretically, change corporate behavior depending on the structure of stakeholders' financial claims.

${ }^{6}$ Duong and Meschke (2020); S. H. Kim (2021) examine whether funds can manipulate their star ratings and find that year-end manipulation disappeared after 2002 because of SEC scrutiny. Our sample focuses exclusively on year-end ratings in the period after 2002 when manipulation is not a concern.
} 
We construct a set of matched treated and control funds that have different star ratings but are indistinguishable on their observable characteristics - including, crucially, the inputs into their Morningstar star ratings. Treated funds are SRI funds that received a high star rating; control funds are non-SRI funds that received a lower star rating in the same fund category and with near-identical lagged returns. While treated and control funds had similar assets and flows in the years prior to treatment, afterward they diverge sharply, with the assets of treated funds increasing by $21 \%$ relative to control funds. We use these relative changes in SRI assets, multiplied by the funds' pre-treatment portfolio weights, to construct plausibly exogenous flows of SRI investment into portfolio firms.

We begin our analysis by using cross-sectional ordinary least squares (OLS) regressions to examine the relation between SRI fund ownership and firms' E\&S conduct. First, we examine the relation between SRI fund ownership and firm-level pollution using data from the EPA. Survey evidence in Krueger et al. (2020) indicates that institutional investors believe climate risks have financial implications for their portfolio firms. As a result, many investors state that they consider pollution when making holding decisions. Consistent with this, we find that SRI fund ownership is strongly related to lower pollution at the firm level. Specifically, more SRI ownership is associated with lower air, land, and water pollution, and with more investments in pollution abatement. Moreover, the results are economically large. A one-standard deviation increase in SRI ownership is associated with 19 percent lower total emissions and a 4.5 percent increase in investments in pollution abatement.

Next, we examine whether SRI fund ownership is related to employee satisfaction, since it has been shown to be related to shareholders' returns (Edmans, 2011). We use data on selfreported employee reviews about their firms from Glassdoor, Inc. We also look at workplace safety using data from OSHA. Consistent with our pollution results, we again find that SRI 
fund ownership is associated with better firm-level outcomes for stakeholders. Employees at firms with more ownership by SRI funds rate their firm better in every category, including career opportunities, compensation benefits, willingness to recommend the company to a friend, confidence in the CEO, future outlook, and overall job satisfaction. Using OSHA data, we find that SRI fund ownership is associated with fewer workplace injuries as measured by hospitalization and amputations.

We also examine broader social dimensions such as gender and racial diversity on the board of directors. Although some research suggests that imposing gender quotas has negative effects on firm valuation and performance (Ahern \& Dittmar, 2012), many institutional investors actively support board diversity and many companies have publicly committed to increase it (Krouse, 2018). We find that firms with more SRI ownership have significantly more women on their board of directors. A one-standard deviation increase in SRI ownership is associated with 0.6 percentage points more women on the board. ${ }^{7}$

One of the unique contributions of our study is that we examine 22 different environmental and social outcomes and we find consistent results across them. However, given the large number of outcome variables we examine, we would expect some outcomes to be statistically significant by chance (a Type I error). ${ }^{8}$ Thus, we apply the Romano and Wolf (2005) adjustment for multiple hypothesis testing. Our conclusions are largely unchanged. Hence, our results provide clear evidence that SRI funds are not greenwashing since they select firms with better E\&S practices. However, it is still unclear whether SRI funds actively work to improve the behavior of their portfolio companies. Put differently, it is unclear whether these

\footnotetext{
${ }^{7}$ We also find that $11 \%$ of the board members in our sample firms are non-Caucasian, but there are no differences between SRI and Non-SRI funds.

${ }^{8}$ In our setting, the probability of making at least one Type I error using a critical value of $5 \%$ is $1-(1-5 \%)^{22}=68 \%$, where 22 is the number of outcomes (assuming independence of tests and all of the null hypotheses are true).
} 
results represent an active treatment effect, or simply a selection effect. To examine this, we next use our novel research design that exploits Morningstar "star ratings" as an exogenous shock to SRI fund capital.

Again, we start by examining pollution. While we find that SRI funds tend to hold companies that pollute less, we find no evidence that SRI funds change a firm's environmental behavior. Specifically, we find that the average increase of $21 \%$ in SRI capital for our treated funds leads to zero change in total pollution or investment in pollution abatement. In other words, the findings are inconsistent with SRI funds improving the environmental behavior of their portfolio firms.

Next, we examine measures of employee well-being. We find some evidence of improvements for employees. In particular, we find a slight improvement in employees' views about career opportunities $(\mathrm{p}$-value $=0.070)$, the company outlook $(\mathrm{p}$-value $=0.087)$, the employees' assessment of the CEO ( $\mathrm{p}$-value $=0.025)$, and the rate hospitalizations ( $\mathrm{p}$-value=0.071). Further, we observe a 0.5 percentage point increase in the fraction of women on boards $(\mathrm{p}$-value $=0.002)$. However, while these results are consistent with a treatment effect, the results show only two variables that are significant at the $5 \%$ level out of 22 different outcome variables. As more outcomes are examined, it is likely that more results will be found due to chance. Accordingly, we again apply the multiple hypothesis testing correction (Romano $\&$ Wolf, 2005). This time, we find that the results do not survive - none of the outcomes are significant after adjusting for the number of hypotheses tested. Taken together, the results show that SRI funds do select companies that behave in a relatively more environmentally and socially responsible manner, but they do not improve the environmental or social conduct of their portfolio firms. Put differently, we find consistent evidence of a selection effect, but not a treatment effect. 
As noted in Abadie (2018), “...rejection of a point null often carries very little information, while failure to reject may be highly informative." However, while our non-results on SRI may be highly informative, there are three main concerns about our non-results. In particular, they may be due to: (1) limited statistical power, (2) a short time horizon, or (3) heterogeneous treatment effects. On the first concern, for each of our treatment-effect estimates we compute the minimum detectable effect size (MDES) as in Bloom (1995). The MDES measures the magnitude of treatment effect that a given estimator could reliably detect. Throughout our analyses, the MDES indicates that we have enough power to reliably detect a meaningful change in real outcomes. On the second concern, we examine longer-run effects on firm outcomes using data two and three years post-treatment. Again, the MDES indicates that these estimates are well powered, yet the point estimates are similar to our main findings. Thus, even at longer horizons, we find no evidence of a treatment effect. On the third concern, it is possible that our non-results are because SRI funds, on average, do not yet own large enough stakes to influence firm policies. To examine this, we perform a variety of sample splits and find no evidence for heterogeneous treatment effects. In particular, we find no evidence that our non-results are different when SRI funds have larger positions. Thus, our non-findings on the effects of SRI funds consistently show there is simply no effect on firm behavior.

Overall, our results suggest that despite their stated objective to engage, SRI funds do not have real effects on their portfolio companies. ${ }^{9}$ Dikolli, Frank, Guo, and Lynch (2021) document that SRI funds, on average, are more likely to vote in favor of environmental and social shareholder proposals compared to non-SRI funds. However, Michaely, Ordonez-

\footnotetext{
${ }^{9}$ Recent work by S. Kim, Kumar, Lee, and Oh (2021) documents similar results for ESG bonds. They find that issuers of ESG bonds tend to have better ESG scores, but these scores do not improve after the bonds are issued.
} 
Calafi, and Rubio (2021) find that SRI funds behave strategically: they vote in favor of environmental and social proposals when they are unlikely to pass, but they vote against them when their vote is more likely to be pivotal. Taken together, the evidence suggests SRI funds primarily operate through portfolio selection rather than by changing firm behavior. This result seems consistent with incentives: investors are happy when their dollars are invested in green companies, which boosts fund managers' compensation. Meanwhile, this avoids costly effort by fund managers and firm managers, who do not have to significantly change their behavior. In sum, our findings suggest that socially responsible funds do not play an important role in improving environmental and social issues.

\section{Background and Data}

\section{A. Related Literature}

While it is unclear whether SRI funds affect corporate behavior, it is clear that investors care about SRI funds. The amount of capital allocated to SRI funds has more than doubled over the last decade (see Figure 1) and a SRI fund recently launched by BlackRock attracted more than $\$ 600$ million in its first week of activity (Coumarianos, 2020). Similarly, Bialkowski and Starks (2016) document an increase in investor demand for socially responsible funds and Hartzmark and Sussman (2019) document a large capital flow into highly rated SRI funds following the 2016 introduction of Morningstar sustainability ratings. Consistent with this phenomenon, survey data in Riedl and Smeets (2017) show that investors are willing to forgo financial performance to invest in accordance with their social preferences. ${ }^{10}$ Similarly,

\footnotetext{
${ }^{10}$ Benson and Humphrey (2008) show that SRI fund flows are less sensitive to returns than conventional funds, and Bollen (2007) finds that cash outflows from SRI funds are less sensitive to lagged negative returns, indicating that investors do appear to derive utility from more than just performance.
} 
Bauer, Ruof, and Smeets (2019) conduct a survey at a major pension fund and find that the majority of investors wants the fund to invest in a sustainable manner, even if it leads to a reduction in performance.

Our paper relates to the theoretical predictions in Davies and Van Wesep (2018), Edmans (2009), and H. L. Friedman and Heinle (2020). Davies and Van Wesep (2018) show that most managerial compensation contracts reward long-run profitability and, as a result, it is unlikely that SRI fund holding decisions will significantly change managerial incentives to engage in E\&S policies. Indeed, they show that SRI fund holding decisions may even decrease incentives to invest in E\&S policies. This is also consistent with Edmans (2009), who shows that exit is less relevant if a firm manager's wealth is tied to long-term firm value, which implies that fund exit decisions may not affect E\&S policies. Finally, H. L. Friedman and Heinle (2020) show that, due to free riding incentives, funds may prefer to invest in companies that have managers with similar E\&S preferences instead of investing in costly efforts to influence behavior.

Our paper also relates to the broad literature on the effects of institutional investors (see Edmans and Holderness (2017) for a complete survey of the literature), and in particular investors interested in environmental and social issues. Chu and Zhao (2019), Akey and Appel (2019), and Naaraayanan, Sachdeva, and Sharma (2020) find that firms targeted by activist investors improve environmental behavior. ${ }^{11}$ Azar, Duro, Kadach, and Ormazabal (2020) find that the Big 3 passive fund families concentrate their engagement activities in large portfolio firms with higher emissions. However, both activist hedge funds and the funds managed by the Big 3 families have varying objectives (and most are not SRI funds). Our paper differs in that we specifically focus on SRI funds. Further, we are the first to examine

\footnotetext{
${ }^{11}$ Similarly, Brav, Jiang, and Kim (2015) show that activist hedge funds do change firm-level behavior.
} 
the social impact on multiple groups of stakeholders, in addition to firms' environmental practices.

Finally, Dyck, Lins, Roth, and Wagner (2019), Gantchev, Giannetti, and Li (2019), and Gibson, Glossner, Krueger, Matos, and Steffen (2021) examine international evidence and find that institutional ownership is associated with better aggregate environmental and social performance. Our results are consistent with theirs, as we find that ownership by U.S. based SRI funds is associated with better environmental and social performance in a number of dimensions. However, we provide an important new fact: the relation between SRI ownership and outcomes is driven primarily by selection, not treatment.

\section{B. Data}

To examine the relation between socially responsible investing and environmental and social (ES) corporate behavior, we combine micro-level data from a wide variety of public and private sources, as discussed below. Detailed definitions of all our variables and their construction are presented in the Appendix in Sections A and B.

We construct a firm-year panel of firms held by U.S. open-end mutual funds for the period from 2010 to 2019. ${ }^{12}$ From the Morningstar database we collect all mutual funds with available star ratings. To identify an SRI fund, we use data from three sources: Bloomberg, Morningstar, and the US Sustainable Investment Forum (US SIF) membership list. First, using the Bloomberg terminal, we hand-collect mutual funds that identify themselves as "social responsible funds" or "SRI funds." Second, we obtain data from Morningstar Socially Conscious data set, which indicates if a fund identifies itself as selectively investing based on certain non-economic principles. These funds may make investments to improve corporate

\footnotetext{
${ }^{12}$ Based on the availability of data in the different tests, the sample period varies. We provide more details about each source of data below.
} 
behavior on such issues as environmental responsibility, human rights, or religious views. An SRI fund identified in this list can take a proactive stance by selectively investing in, for example, environmentally friendly companies or firms with good employee relations. This list also includes funds that may avoid investing in companies in the defense industry or companies involved in promoting alcohol, tobacco, or gambling. Third, the Forum for Sustainable and Responsible Investment (US SIF) is a U.S.-based membership association that advances impact investing across all asset classes. We manually match institutions in the union of the three lists with those in the Center for Research in Security Prices (CRSP) Mutual fund holdings database, from which we retrieve information about each fund's asset under management (AUM), turnover ratio, management fees, expense ratio, and portfolio holdings, which allow us to measure the percentage of a firm's ownership held by SRI funds (SRI Investment).

Figure 1 shows the substantial growth in SRI funds' number and AUM over time. While the trend is strongly upward and shows a growing interest in socially responsible investing, we note that the total assets under management in SRI funds remains modest, approximately $\$ 240$ billion as of December 2019. The average firm-year in our sample has 0.24 percent of its market capitalization owned by SRI funds (Table I).

We aim to examine corporate behavior on environmental and social issues. Hence, we collect firm-year level data from several different data sources. Our paper is among the first to use novel micro-level data to examine firm behavior. To examine firm environmental behavior, we obtain detailed plant-chemical level pollution data from the Environmental Protection Agency (EPA)'s Toxic Release Inventory database. Also, from the EPA Pollution Prevention database, we collect information about a facility's yearly investments in pollution reducing activities. 
In Table I we report descriptive statistics for the EPA data. On average, firms in our sample release 1.5 million pounds of chemicals per year: 470 thousand pounds into the air, 130 thousand pounds into the water, 680 thousand thousand pounds into the land, 220 thousand pounds off-site, and 4,210 pounds of releases due to non-routine production. Furthermore, firms in our sample invest in 3.6 abatement activities every year, on average, which result in 43 percent of our sample firms investing in pollution reducing activities. Finally, we examine a holistic measure of firms' exposure to climate risk using data from Sautner, van Lent, Vilkov, and Zhang (2020) (CCExposure). ${ }^{13}$ This measure is based on machine learning algorithm that identifies a firm's annual climate change exposure from earnings conference calls. Our sample mean (1.00) is consistent with Sautner et al. (2020).

We also aim to examine each firm's social behavior. To do so, we use four different data sources with micro-level data. To measure employee satisfaction, we obtain data on employee reviews from Glassdoor, Inc., which is a worldwide leader in providing insights about jobs and companies. From the U.S. Department of Labor, Occupational Safety and Health Administration (OSHA), we obtain data on workplace safety. In Table I, we find that firms report an average of 1.86 employees' injuries that require hospitalization, and 0.52 employees' injuries that require amputations each year. We use BoardEx data to measure gender diversity on the board of directors, and from Institutional Shareholder Services (ISS) database we retrieve data on racial diversity on the board. In our sample, firms have on average 16 percent of their board represented by women and 11 percent of their board represented by non-caucasian directors (Table I).

\footnotetext{
${ }^{13}$ We thank the authors for making this data publicly available, see https://osf.io/fd6jq/
} 


\section{Research Design}

\section{A. Selection vs. Treatment}

We begin our analysis by examining the correlations between SRI investment and firm environmental and social behavior, using cross-sectional OLS regressions with year fixed effects. However, we note that there are two main channels that could lead to significant results in OLS regressions of firm behavior on SRI investment. The first channel is that SRI funds could select firms that are already behaving in a responsible manner (i.e., a selection effect). The second channel is that SRI investment could cause changes in firms' behavior (i.e., a treatment effect).

Disentangling these channels is difficult, because it requires us to isolate flows of investor capital into SRI funds that are not related to the SRI funds' investing priorities, or their performance, or the present or intended policies at their portfolio firms. To do this, we make use of funds' Morningstar star ratings. Each month Morningstar assigns each fund in their database an integer number of stars, from 1 to 5, within the fund's investment category. The star rankings are a complex nonlinear function of each fund's percentile ranking, within its category, on the basis of their returns over a three, five, and ten year lagged basis, adjusted for the fund's return volatility over the same period. ${ }^{14}$ Crucially, these are the only inputs that determine funds' star ratings.

The mapping from lagged returns to Morningstar stars allows us to construct a matched set of funds that are indistinguishable on all observable characteristics - including their investment category and lagged returns in the Morningstar database - but had different Morningstar star ratings. We select all U.S. equity funds in the Morningstar database with

\footnotetext{
${ }^{14}$ For a detailed primer on the assignment of Morningstar stars, see Reuter and Zitzewitz (2021).
} 
at least $\$ 50$ million in AUM, in December of each year from 2012 to $2018 .{ }^{15}$ Our matched sets of treated and control funds satisfy the following requirements: The treated fund is an SRI fund, as defined in Section II.B. The treated fund is matched with a control fund that: (1) is a non-SRI fund; (2) is in the same Morningstar category as the treated fund; (3) has assets under management within +/- $50 \%$ of the treated fund; (4) has lagged three, five, and ten year adjusted returns that are within $+/-50$ basis points of the treated fund; (5) is assigned one fewer star than the treated fund in January of the following year. When a treated fund has multiple candidate control funds that satisfy the requirements above, as happens in the majority of cases, we pick up to three control funds with the closest three, five, and ten year adjusted returns to the treated fund, weighted equally.

Figure 2 compares treated versus control funds. We see that the two groups of funds are very closely matched in terms of the 3-year, 5-year, and 10-year Morningstar returns the inputs that determine the Morningstar star ratings. The differences in means between the two groups are 8, 10 and 9 basis points respectively, and the differences are not statistically significant. Appendix Section C presents formal tests of the match quality between the matched samples on a variety of fund characteristics, as well as tests of conditional independence of treatment status. We find that treated and control funds are indistinguishable on all characteristics we examine, including AUM, turnover, expense ratio, and 3-year, 5-year, and 10-year returns.

\section{B. Exogenous changes in fund assets}

Having established that treated and control funds are indistinguishable, ex ante, on observable characteristics, we next examine how Morningstar ratings affect investor flows

\footnotetext{
${ }^{15}$ Our data runs from 2010 to 2019 . We select cohorts from 2012 to 2018 so that each cohort has three years of pre-treatment observations and at least one year of post-treatment observations.
} 
into funds. Figure 3 shows the AUM for treated and control funds in event time relative to the cohort-year. We find that the two groups of funds have similar pre-treatment trends in their AUM, while post-treatment their AUMs diverge sharply. In particular, the AUM of treated funds (which receive a higher star rating) increases on average, while the AUM of control funds (which receive a lower star rating) decreases on average post-treatment. The results show investors differentially allocate capital based on Morningstar star ratings despite the funds' similar underlying fundamentals.

Table II, Column 1 shows the corresponding regression estimate of the treatment effect on funds' AUM. We estimate cohort difference-in-differences regressions that compare fund AUM for treated versus control funds, three years pre-treatment to three years posttreatment. Formally, we examine regressions of the form:

$$
\log A U M_{i, t}=\beta(\text { Treated } \times \text { Post })+F E_{i}+F E_{t}+\epsilon_{i, t},
$$

The estimates include both fund-by-cohort fixed effects, which sweep out any non-timevarying differences across funds, and year fixed effects which sweep out common trends in fund assets. ${ }^{16}$ The results show that treated funds have AUM that is 22.9 log points higher $(t=3.2)$ than control funds because of the difference in their star ratings. These additional investment dollars, driven by the arbitrary cutoffs in the Morningstar ratings, are plausibly unrelated to the treated funds' performance or objectives.

\footnotetext{
${ }^{16}$ Note that this specification also sweeps out any differences in the Morningstar assignment variables - that is, controls for funds' lagged returns or category-by-year fixed effects would be collinear with the fund-by-cohort fixed effects.
} 


\section{B.1. Placebo Specification}

To further ensure that our research design is capturing investor flows driven only by the Morningstar ratings and not by some omitted variable, we repeat the exact matching exercise described in Section II.A above, but we require treated and control funds to have the same Morningstar star rating. This serves as a placebo (or falsification) test since we compare funds that had similar underlying fundamentals, as in our main specification, but that had the same Morningstar star rating. Table II, Column 2 shows the resulting difference-indifferences estimate. In contrast to our first specification, shown in Column 1, we find there is no significant difference in AUM between treated and control funds post-treatment, either economically or statistically (0.8 log points, $t=0.1)$.

\section{B.2. Removing Aggregate Trends in Fund Assets}

One possible concern for our research design is that our results may reflect aggregate trends in fund assets over time, rather than the pure effect of the Morningstar star ratings on fund assets. For example, because SRI funds are increasing their assets throughout the sample (both in absolute terms and relative to non-SRI funds), perhaps they were more likely to have higher AUM in later (post-treatment) years independent of their Morningstar rating.

To examine this possibility, we orthogonalize each funds' $\log (\mathrm{AUM})$ to yearly trends within each Morningstar category, separately for SRI and non-SRI funds. To do this, we demean each fund's $\log (\mathrm{AUM})$ by its Morningstar category, interacted with the year, interacted with SRI fund status. Thus, the "Residualized" $\log (\mathrm{AUM})$ removes year-by-year trends in assets under management, within each Morningstar investment category each year, for SRI and non-SRI funds separately. Table II, Column 3 shows the main difference-in-differences 
estimate, where the outcome variable is the residualized fund AUM. The results are nearly identical to our first specification, shown in Column 1. Namely, we observe a large difference in AUM between treated and control funds (21.3 log points, $t=3.3)$ post-treatment.

\section{Exogenous changes in SRI investment}

Our results show that the discontinuous assignment of Morningstar ratings leads to a relative increase in assets under management for our treated funds. However, one concern is that after an exogenous increase in AUM, fund managers may choose which stocks to invest the additional capital in, and this choice could lead to an omitted variable bias. Accordingly, we project the treatment effect of $21.3 \%$ of assets (Table II Column 3) onto treated funds' holdings as of the December just prior to treatment. That is, for each fund in the matched set, we compute the fitted value of the difference-in-differences estimate for fund assets, and multiply that change by that fund's pretreatment holdings of each U.S. firm in the merged CRSP/Compustat data. ${ }^{17}$ The resulting value, fund-by-firm-by-year, is the projected change in investment by that fund in that firm, holding the fund's portfolio composition fixed after treatment (i.e., with no look-ahead bias). For a control fund, this value is zero for all firms and years. For a treated fund, this value is zero in pre-treatment years, and a positive fraction of firm value in post-treatment years.

Summing the fitted values by firm-year, we obtain a single fitted value for each firm-year. The value is zero for firms that were never held by a treated fund, and for firms that were held by any treated fund in pretreatment years. The value is a positive fraction of firm value for firms that were held by at least one treated fund in post-treatment years. Thus,

\footnotetext{
${ }^{17} \mathrm{~A}$ key requirement for this approach is that the inflows into treated funds were, on average, allocated pro rata to the fund's existing portfolio. We examine this requirement in Appendix Section D, and confirm that this is the case.
} 


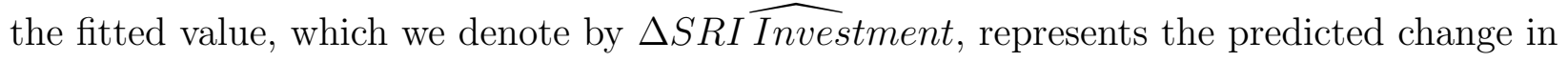
SRI investment for each firm in the sample, that flows from our matched funds difference-indifferences setting. Put differently, it is a difference-in-differences estimator at the firm-year level, with a continuous treatment intensity for each firm-year. We then use this to examine regressions of the form:

$$
y_{j, t}=\beta * \Delta S R I \widehat{\text { Investment }}{ }_{j t}+F E_{j}+F E_{t}+\epsilon_{j, t}
$$

where $y_{j, t}$ is a measure of environmental or social behavior. All estimates include firm fixed effects, which sweep out any non-time-varying differences across firms, and year fixed effects which sweep out time trends.

\section{Results}

We examine the environmental and social impact of SRI funds by conducting two types of analysis. First we examine the portfolio selection choices of SRI funds. Second, we examine the treatment effects of SRI funds on the environmental and social behavior of their portfolio firms. Our analyses are centered around three environmental and social pillars: the environment, employee satisfaction and safety, and gender and racial diversity.

\section{A. Selection Effects}

\section{A.1. SRI funds and firm-level environmental behavior}

Based on their stated objective, SRI funds should select firms with lower emissions. In this section, we examine micro data on firms' emissions from the EPA Toxic Release Inventory data which allows us to understand whether a firm's actual pollution is an input in SRI 
portfolio selection strategies. The EPA data provides granular information about firm-level emissions at the production facility (on site), about the emissions transferred on a different location (off site), as well as dis-aggregated information broken out into air, ground, and water pollution. We use OLS regressions with year fixed effects to examine the association between SRI ownership and emissions. The results are reported in Table III.

We find strong evidence that SRI funds select firms that pollute less. A one standard deviation increase in SRI ownership is associated with 19 percent lower total emissions (scaled by total sales, Column 1). To put this number in perspective, this relation implies that firms owned by SRI funds have an average of 296 thousand pounds less of toxic chemicals releases per year, which is approximately 20 percent of the unconditional mean of total releases across firms. This result indicates that SRI funds provide investors with a portfolio of firms that pollute significantly less than the average firm.

The granularity of the EPA data allows us to go a step further and examine different pollution mechanisms - namely air, water and ground. Most industrial pollution involves air emissions, although in terms of pounds produced, ground emissions represent the largest share given the different chemicals emitted (see Table I for more details). We examine the relation between SRI funds and different types of emissions in Columns 2 to 4 of Table III. We find that SRI funds invest in firms that pollute less across the board, although the relation with air seems to be predominant, consistent with anecdotal evidence. ${ }^{18}$

In addition to on-site releases into the air, land, and water, we also examine total releases which include off-site releases (these are emissions transferred off site for disposal). Moreover,

\footnotetext{
${ }^{18}$ BlackRock's Investment Stewardship team claims to regularly engage with companies to understand how material environmental factors are considered from the perspective of risk and opportunity. Gas emissions are a key focus area in their engagements with portfolio companies as consensus grows around the impact of climate change on financial markets, companies' performance, and society. See https://www.blackrock .com/corporate/literature/publication/blk-commentary-engaging-on-emissions.pdf.
} 
any toxic chemical released to the environment or transferred off site due to events not associated with routine production processes is not included in the total releases. Hence, to provide a complete picture of a firm's pollution production, we also examine off-site releases and one time releases. Results are reported in Columns 5 and 6 of Table III. We find negative associations between SRI funds' ownership and both off-site releases and one time releases of pollution.

Next, we examine firm investments in pollution reducing activities (i.e., investments in abatement technologies). This analysis allows us to shed light on the channels that drive portfolio selection by SRI funds. Firms document their investments to reduce emissions in their annual fillings to the EPA. The EPA does not require firms to report the dollar amounts spent on these investments, but firms must disclose what types of actions they take according to seven categories of pollution reduction. We combine these disclosures into two variables: Abatement, which takes the value of one if the firm reports an abatement activity across any category and is zero otherwise, and logAbatements which is the log of one plus the number of abatement actions that a firm discloses in a given year. Columns 7 and 8 of Table III show the association between SRI ownership and firms' investment in pollution abatement activities. We observe that SRI funds tend to hold firms that are $2.2 \%$ more likely to invest in pollution abatements, and the firms they hold invest $4.5 \%$ more in pollution abatements.

Finally, we examine a holistic measure of firms' exposure to climate risk. Sautner et al. (2020) use machine learning algorithms to measure exposure to climate change risk at the firm-year level. We examine the relation between SRI ownership and their measure of climate change exposure, CCExposure; the results are shown in Table III Column 9. We find that SRI ownership is strongly negatively associated with a firm's exposure to climate risk. Sautner et al. (2020) show firms with higher carbon intensity are more exposed to climate 
risk. Consistent with this finding, we observe that SRI funds select firms that pollute less and those firms have 6.1 percent lower climate risk exposure.

One concern related to statistical inference is that we examine the association between SRI ownership and firm behavior across a large number of outcome variables. If uncorrected, this multiple-testing can lead to a large number of false positive findings (Heath, Ringgenberg, Samadi, \& Werner, 2021). To account for this, we present both naive (i.e. unadjusted) $p$-values for each estimate as well as $p$-values adjusted for multiple testing using the RomanoWolf procedure (Romano \& Wolf, 2005). We see that after adjustment for multiple testing, some of the more detailed tests become insignificant. However, the main associations of SRI with the key measures of total pollution (Column 1), airborne and water pollution (Columns 2 and 3) remain significant at conventional levels. Taken together, our results show that SRI funds select firms that pollute less and invest more in pollution-reducing activities.

\section{A.2. SRI funds and employee well-being}

Next, we examine whether SRI funds select firms with better employee well-being. We begin by looking at workplace safety and employee satisfaction, which has been shown to be positively correlated with shareholder returns (Edmans, 2011). In our analysis, we use private data on several dimensions of employee satisfaction provided by Glassdoor, Inc. and public data on workplace accidents available through the Department of Labor - Occupational Safety and Health Administration (OSHA). The results are shown in Table IV Panel A.

Across the board, we find positive relations, both overall and in regard to career opportunities, compensation benefits, work/life balance, corporate culture, willingness to recommend the company to a friend, confidence in the CEO, and future outlook. These positive associations are statistically significant at conventional levels for 3 of the 9 measures individually, 
while after adjustment for multiple testing it is only significant for the association with employees' future outlook. Thus, while the evidence is weaker statistically than for environmental behavior, SRI funds do tend to invest in firms with higher employee satisfaction.

Furthermore, we examine the relation between SRI fund ownership and workplace safety. For accidents that resulted in either hospitalizations (Column 10) or amputations (Column 11) we observe negative associations. The association with fewer hospitalizations is statistically significant at the one percent level both individually and after adjustment for multiple testing. Thus, we conclude that SRI funds invest in firms with significantly better workplace safety.

Finally, we examine gender and racial diversity in the workplace. The results are shown in Table IV Panel B. We examine corporate diversity on the board of directors since board diversity is one of the most controversial topics in corporate governance given the recent considerable attention on the composition of boards of directors in terms of gender quotas (Lublin \& Krouse, 2017). ${ }^{19}$ Although some research shows that imposing gender quotas has significant negative effect on firm valuation and performance (Ahern \& Dittmar, 2012), many institutional investors actively support board diversity and publicly commit to increase it (Krouse, 2018). Similarly, NASDAQ is considering a proposal to advance diversity through a new listing requirements, ${ }^{20}$ and some state's have enacted legislation requiring gender or racial diversity for companies headquartered or operating in their states. ${ }^{21}$ As a result, many directors now recognize board diversity as a major issue of importance. ${ }^{22}$

\footnotetext{
${ }^{19}$ Further, a recent study documents that some funds have a gender bias when making portfolio allocations (H. Friedman, 2020)

${ }^{20} \mathrm{https}$ ://www .nasdaq.com/press-release/nasdaq-to-advance-diversity-through-new-proposed -listing-requirements-2020-12-01

${ }^{21}$ https://www.wsj.com/articles/california-lawmakers-mandate-racial-diversity-on -corporate-boards-11598915372

${ }^{22}$ https://www . akingump.com/a/web/113016/aokJr/top10_directors_010820-4.pdf
} 
In Table IV Panel B, we find that SRI funds select firms with more women on the board of directors. A one standard deviation increase in SRI ownership is associated with 0.6 percentage points more women on the board, but is not associated with more non-Caucasian board members. The findings are consistent with Gow, Larcker, and Watts (2020) who show that shareholders are more likely to support gender diverse candidates than racially diverse candidates. While the economic magnitudes of these findings may seem small, the effects are meaningful relative to the unconditional mean values in our sample (women represent only $16 \%$ of board members). The association of SRI investing with gender diversity is statistically significant both individually and after adjustment for multiple testing.

Overall, our findings show that the welfare of the employees - their satisfaction and workplace safety as well as gender diversity on the board of directors - are important determinants of an SRI fund's investment strategy. This confirms our prior findings: SRI funds offer their investors a portfolio of firms with stronger environmental and social performance, consistent with those funds' stated objective.

\section{B. Treatment Effects}

Our results so far show that SRI fund ownership is strongly associated with better firm behavior on environmental and social dimensions. However, it remains unclear whether SRI funds actually affect the behavior of their portfolio firms. In other words, the positive association could be due to selection or treatment effects. Dikolli et al. (2021) document that SRI funds vote strongly in favor of environmental and social shareholder proposals thus, there is the potential for SRI funds to affect their portfolio firms. Next, we examine whether SRI funds produce real effects. 


\section{B.1. SRI funds and firm-level environmental behavior}

In Table III we found that SRI fund ownership is associated with lower emissions. Here, we examine whether SRI fund ownership causes changes in pollution. Table V implements our difference-in-differences design that uses exogenous variation in SRI fund ownership to examine EPA pollution data. For only one of the six measures of toxic releases (land), the estimate of the effect of SRI investment is negative. For the other five measures including total releases and one-time releases, the point estimate is positive, inconsistent with emissions reduction. Moreover, none of the estimates is statistically significantly different from zero.

It is possible that significant reductions in pollution take time to occur. Accordingly, we also examine whether SRI ownership leads to investments in pollution abatement activities, which might happen more quickly and lead to future emissions reduction. If SRI funds aim to reduce pollution of their firms, then we should observe greater investments in abatement technologies of SRI funds' portfolio firms. The results show no effect of SRI funds ownership on abatements at the extensive margins (Column 7) or at the intensive margins (Column 8). We also find no significant effect on climate risk exposure (Column 9).

In general, we observe that the point estimates in Table $\mathrm{V}$ are all small in magnitude. One important question for our difference-in-difference estimates is whether our research design is adequately powered to detect a significant treatment effect. If not, then our finding that SRI

fund ownership has no effect on emissions could be due to our estimates being underpowered. To examine this possibility, for each of our estimates we compute the minimum detectable effect size (MDES) following Bloom (1995). The MDES is a simple measure of the magnitude of treatment effect that a given estimator can reliably detect. The MDES of our estimates suggests that our research design is adequately powered to detect an effect in the order of 3 to 9 percent of the average firm's emissions. For example, in the case of the log number 
of pollution abatements (Column 8), our research design could reliably detect a treatment effect on the order of 0.074 or larger. The number of abatements in our sample has a mean of 3.6 and a standard deviation of 15.4 - in logs, it has a mean of 0.70 and a standard deviation of 1.01. Thus, our research design could reliably detect a treatment effect of a magnitude less than $1 / 14$ of one sample standard deviation. We conclude that our research design is well-powered for all nine outcomes examined in the table. To the extent that we do not find an effect of SRI fund ownership on pollution and abatements, it is because there is no meaningful effect, at least for the funds and firms in our sample.

Another concern related to statistical inference is that we simultaneously look for the effects of increased SRI ownership on firm behavior across a large number of outcome variables. If uncorrected, this approach can lead to an inflation in the rate of false-positive findings, because individual significance tests do not take into account the reuse of the same natural experiment (Heath, Ringgenberg, et al., 2021). To account for this issue, we present both naive (unadjusted) $p$-values for each estimate as well as $p$-values adjusted for multiple testing using the Romano-Wolf procedure (Romano \& Wolf, 2005). We observe that under both approaches, none of the pollution-based measures show a statistically significant effect.

While our main analyses examine dependent variables measured over the year that immediately follows treatment, it is possible that SRI funds change firm behavior at longer horizons. To account for this possibility, we examine changes in firm behavior at longer (two- and three-year) horizons. The results are shown in Table A3. The MDES again suggests that our estimates are well powered, and we again find zero significant effects of SRI ownership on firm-level pollution. ${ }^{23}$ In other words, even at the two- and three-year horizon, we find no evidence that SRI funds change firm-level behavior.

\footnotetext{
${ }^{23}$ Our conclusions are unchanged if we drop firm-year-pollutant observations that have a value of zero or if we examine raw values, instead of scaling by sales.
} 
Our results so far suggest that SRI funds select firms that pollute less. Yet, SRI funds do not improve firm-level pollution. In other words, we do not observe any changes in the environmental behavior of firms due to ownership by SRI funds. Our results are consistent with Bartram, Hou, and Kim (2019), who show that some firms shift emissions and plant ownership from California to other states to avoid stringent regulation on plant emission. In our setting, the fact that firms do not reduce pollution nor do they change their in investment in pollution abatements suggest that the marginal cost of pollution reduction remains higher than the marginal benefit.

\section{B.2. SRI funds and employee well-being}

Next, we examine whether SRI fund ownership leads to improved employee well-being. First, we examine employee satisfaction and workplace safety in Table VI Panel A. Then we examine board of directors diversity in Table VI Panel B. In Panel A, we find that an exogenous increase in SRI fund ownership is followed by insignificant or small positive changes in employee satisfaction. All nine measures of employee satisfaction increase on average following treatment. However, we observe that an increase in SRI fund ownership is followed by a decrease in workplace safety as measured by hospitalizations.

Once again, the MDES calculations suggest that our research design is adequately powered. Before adjusting for multiple testing, the treatment effect is statistically significant for four measures, reflecting an improvement in career opportunities, confidence in the CEO, overall firm outlook, and an increase in hospitalizations. However, the magnitudes of all of these effects are quite small, and after adjusting for multiple testing none of them is statistically significant at conventional levels as shown by the Romano-Wolf $p$-values. Thus, the data are consistent with the effects shown in Panel A being artefacts of multiple testing and 
not true treatment effects. Overall, we cannot reject the null that SRI fund ownership has no causal effect on employee satisfaction and safety. Put differently, while SRI funds invest in firms with higher employee satisfaction and safety, SRI funds do not cause improvements in these outcomes.

As in our selection analyses, we also examine the board of directors' gender and racial diversity. In Table VI, Panel B, we find that an exogenous increase in SRI fund ownership is followed by an increase in women on the board of directors, but no significant changes in racial diversity. Again, the MDES calculations suggest that our research design is adequately powered. For example, the MDES for gender diversity is 0.4 percentage points, so our research design could and does reliably detect a change in board diversity of 0.5 percentage points.

However, again, after adjusting for multiple testing the Romano-Wolf $p$-value is not significant at conventional levels. Since the cross-sectional association reported in Table IV is a 0.6 percentage points increase in gender diversity per standard deviation increase in SRI fund ownership, results in Table VI suggest that all or most of that association is not due to a treatment effect, but rather to SRI funds' selection. In other words, while SRI funds select firms with more diverse boards in order to fulfill their social goals, they do not significantly increase the proportion of women or of non-white directors at their portfolio firms.

\section{B.3. Heterogeneous treatment effects of SRI funds ownership}

In our final set of tests we examine potential heterogeneity in our treatment effect. While SRI funds AUM has substantially increased over the last ten years (see Figure 1), the average SRI fund's ownership is still relatively small (0.24\% of shares outstanding in our sample). It is possible that our non-results indicate that SRI funds are not large enough to influence 
company-level policies. However, there is variation in the position sizes of SRI funds - with SRI funds in the top decile holding approximately $0.7 \%$ of shares outstanding in a company. To examine whether our non-results are due to the small average position size of many funds, we test for heterogeneity in the treatment effect by splitting firms into terciles of SRI ownership prior to the shock. In other words, we examine whether the effect of SRI ownership is different for firms with higher versus lower preexisting levels of SRI fund ownership.

The results are reported in Table VII, Panel A; for brevity, we present estimates for a subset of the main outcomes examined in our prior analyses, however the findings are similar across all of our outcomes variables. We continue to find no significant effect of SRI funds ownership on total releases and investments in abatement activities. In contrast, we do find an effect on overall employee satisfaction and the fraction of women on boards for firms in the top terciles of SRI funds ownership. However, F-tests for heterogeneity in the treatment effect show no significant differences between funds with large versus small position sizes for either outcome. Taken together, these results suggest that our non-results are unlikely to be caused by the small size of SRI funds. Of course, an SRI fund with a much larger ownership stake is likely to change corporate policies, but in modern capital markets with diffuse ownership, our results suggest that SRI funds typically do not own enough shares to affect change. These findings are broadly consistent with Teoh, Welch, and Wazzan (2009) who show that shareholder divestitures protesting apartheid in South Africa had little effect despite the widespread attention they received.

A further concern may then be that SRI funds do not change firm policies because they hold companies that already outperform in terms of E\&S practices. In other words, we cannot expect employees satisfaction to be improved any further in a company that reports the highest employees ratings. In Table VII, Panel B we address this concern. We test for 
heterogeneity in the treatment effect by conditioning on terciles of a firm's environmental or social performance prior to the shock to SRI ownership. In other words, we examine whether the effect of SRI ownership on emissions and abatement is different for firms that have high versus low environmental scores from KLD (Columns 1 and 2). Similarly, we examine whether the effect of SRI ownership on employee satisfaction and the percentage of women on boards is different for firms that have high versus low social scores from KLD (Columns 3 and 4).

We continue to find no effect of SRI funds ownership on total releases and investments in abatement activities. We find an effect on overall employee satisfaction and the fraction of women on boards. However, similar to results in Panel A, F-tests for heterogeneity in the treatment effect show no significant differences between funds with large versus small position sizes.

Finally, it is possible that many of the SRI funds in our sample are passively managed funds that do not intend to change firm behaviour. Heath, Macciocchi, Michaely, and Ringgenberg (2021) show that passively managed funds are, on average, less effective at monitoring and changing firm behavior than actively managed funds. Put differently, perhaps actively managed SRI funds do change behavior, but our sample is dominated by passively managed SRI funds. To explore this possibility, rows 2 and 3 of Table I examine the portion of SRI funds that are actively managed versus passively managed. The results show that virtually all SRI ownership at the firm level is by actively managed SRI funds. As of 2019, the last year in our sample, passively managed SRI funds were a small minority both by number (80 of 602 total SRI funds) and by assets under management ( $\$ 25$ billion of $\$ 240$ billion total AUM in SRI funds). ${ }^{24}$ Thus, the two recent booms in passive investing and

\footnotetext{
${ }^{24}$ In addition to accounting for only one-tenth of SRI fund assets, passive funds invest in a more diversified portfolio on average, so they account for even less of the average SRI ownership by firm.
} 
socially responsible investing (SRI) are almost entirely disjoint from each other.

\section{Conclusion}

While there is an active debate about the role of institutional investors in society (Hart \& Zingales, 2017), to date there is little evidence on whether socially responsible investing actually affects corporate behavior. We provide novel evidence on the actions of SRI funds. We find that SRI funds are significantly more likely than non-SRI funds to hold firms with good environmental and social behavior. SRI funds tend to hold companies that pollute less, have better workplace safety, have greater board diversity, and have better employee satisfaction. However, despite this, we find little evidence that SRI funds succeed in changing corporate behavior. In particular, we find no evidence that SRI contributes in reducing firms' pollution, improving employee satisfaction, improve workplace safety, or gender and racial diversity on corporate boards. Our results suggest that while SRI funds are successful in providing their investors with a portfolio of environmentally and socially responsible firms, they do not change corporate behavior of their portfolio firms. Hence, investors who want to change real world behavior might be investing in the wrong firms. Put differently, it is difficult to reduce pollution in a company that is already doing everything it can to reduce pollution. Instead of investing in the best behaving companies, SRI investors might have a bigger impact if they invested in the worst behaving companies. ${ }^{25}$ Future research should explore the best way for socially responsible investing to generate positive outcomes along environmental and social dimensions.

Of course, there are several possible explanations for our results. First, it is possible that

\footnotetext{
${ }^{25}$ Consistent with this, Cohen et al. (2020) show that oil, gas, and energy-producing firms (who tend to have the worst ESG scores) are key contributors to the invention of environmentally friendly technology.
} 
SRI is successful at changing corporate behavior, but only over longer horizons. However, we note that while some outcomes such as greenhouse emissions and corporate culture may take a long-time to change, other outcomes such as corporate diversity, and employee satisfaction may change over a shorter period of time, as boards are elected annually and employee complaints are filed daily. Yet, we find no evidence of a change for any outcome. We also look for longer-run effects on firm behavior two and three years post-treatment, and again we find zero or slightly negative effects.

It is also possible that SRI funds indirectly cause firms to behave differently via entry or exit. For example, a firm could reduce its pollution in order to attract capital from SRI funds. While it is inherently challenging to examine whether firms change their behavior because of the threat of entry or exit, we find little evidence that catering, as a strategy, is valuable for firms. In Table A4 of the Appendix, we show that SRI funds do not allocate more (or less) capital to firms that recently change their environmental or social policies. Put differently, even if we cannot rule out the possibility that firms could change their behavior to attract SRI funds, such a strategy does not appear to pay off. Overall, our results add important evidence to the debate on social responsibility: on average, SRI funds choose to invest in better behaving companies, but they do not improve firm behavior. 


\section{References}

Abadie, A. (2018). Statistical non-significance in empirical economics. NBER Working Paper. Retrieved from http://www.nber.org/papers/w24403.pdf

Ahern, K. R., \& Dittmar, A. K. (2012). The changing of the boards: The impact on firm valuation of mandated female board representation. The Quarterly Journal of Economics, 127(1), 137-197.

Akey, P., \& Appel, I. (2019). Environmental externalities of activism. Working Paper.

Azar, J., Duro, M., Kadach, I., \& Ormazabal, G. (2020). The big three and corporate carbon emissions around the world. Working Paper.

Bartram, S. M., Hou, K., \& Kim, S. (2019). Real effects of climate policy: Financial constraints and spillovers. Fisher College of Business Working Paper(2019-03), 004.

Bauer, R., Ruof, T., \& Smeets, P. (2019). Get Real! Individuals Prefer More Sustainable Investments. Working Paper.

Bebchuk, L. A., \& Tallarita, R. (2020). The illusory promise of stakeholder governance. Available at SSRN 3544978.

Bénabou, R., \& Tirole, J. (2010). Individual and corporate social responsibility. Economica, r.7, $1-19$.

Benson, K. L., \& Humphrey, J. E. (2008). Socially responsible investment funds: Investor reaction to current and past returns. Journal of Banking \& Finance, 32, 1850-1859.

Berg, F., Fabisik, K., \& Sautner, Z. (2020). Rewriting history ii: The (un) predictable past of esg ratings. European Corporate Governance Institute-Finance Working Paper, 708.

Berg, F., Koelbel, J. F., \& Rigobon, R. (2019). Aggregate confusion: The divergence of esg ratings. MIT Sloan School of Management.

Bialkowski, \& Starks. (2016). SRI Funds: Investor Demand, Exogenous Shocks and ESG 
Profiles. Working Paper.

BlackRock. (2020). Emissions, engagement, and transition to a low low-carbon economy. Retrieved March 2020, from https://www.blackrock.com/corporate/literature/ publication/blk-commentary-engaging-on-emissions.pdf

Bloom, H. S. (1995). Minimum detectable effects: A simple way to report the statistical power of experimental designs. Evaluation Review, 19(5), 547-556.

Bollen, N. P. B. (2007). Mutual fund attributes and investor behavior. The Journal of Financial and Quantitative Analysis, 42, 683-708.

Brav, A., Jiang, W., \& Kim, H. (2015). The real effects of hedge fund activism: Productivity, asset allocation, and labor outcomes. Review of Financial Studies, 28, 2723-2769.

Chowdhry, B., Davies, S. W., \& Waters, B. (2019). Investing for impact. Review of Financial Studies, 32, 864-904.

Chu, Y., \& Zhao, D. (2019). Green hedge fund activists. Available at SSRN 3499373.

Cohen, L., Gurun, U. G., \& Nguyen, Q. (2020). The ESG - Innovation Disconnect: Evidence from Green Patenting. Working Paper.

Coumarianos, J. (2020, Feb). Blackrock drives esg with new etfs and draws a $\$ 600$ million investment. Barron's.

Davies, S. W., \& Van Wesep, E. D. (2018). The unintended consequences of divestment. Journal of Financial Economics, 128, 558-575.

Dikolli, S. S., Frank, M. M., Guo, M. Z., \& Lynch, L. J. (2021). Walk the talk: Esg mutual fund voting on shareholder proposals. Available at SSRN 3849762.

Dimson, E., Karakaş, O., \& Li, X. (2015). Active ownership. The Review of Financial Studies, 28(12), 3225-3268.

Domini Social Equity Fund. (2021). Sustainable, responsible and impact mutual fund and etf chart - fund profile: Domini social equity fund. Retrieved June 2021, from https:// 
charts.ussif .org/mfpc/fund_profile_display .php?FundID=94

Duong, T. X., \& Meschke, F. (2020). The rise and fall of portfolio pumping among us mutual funds. Journal of Corporate Finance, 60, 101530.

Dyck, A., Lins, K. V., Roth, L., Towner, M., \& Wagner, H. F. (2020). Renewable governance: Good for the environment? Working Paper.

Dyck, A., Lins, K. V., Roth, L., \& Wagner, H. F. (2019). Do institutional investors transplant social norms? International evidence on corporate social responsibility. Journal of Financial Economics, 131, 693-714.

Edmans, A. (2009). Blockholder trading, market efficiency, and managerial myopia. The Journal of Finance, 64(6), 2481-2513.

Edmans, A. (2011). Does the stock market fully value intangibles? employee satisfaction and equity prices. Journal of Financial economics, 101 (3), 621-640.

Edmans, A., \& Holderness, C. G. (2017). Blockholders: A survey of theory and evidence. The handbook of the economics of corporate governance, 1, 541-636.

Edmans, A., \& Manso, G. (2010). Governance through trading and intervention: A theory of multiple blockholders. The Review of Financial Studies, 24(7), 2395-2428.

Forum for Sustainable and Responsible Investing. (2021). Sustainable investment mutual funds and etfs chart. Retrieved from https://charts.ussif.org/mfpc/

Friedman, H. (2020). Investor preference for director characteristics: Portfolio choice with gender bias. The Accounting Review, 95(5), 117-147.

Friedman, H. L., \& Heinle, M. S. (2020). Interested intermediaries. Working Paper.

Friedman, M. (1970, 01). The social responsibility of business is to increase its profits. New York Times Magazine, 32, 173-178. doi: 10.1007/978-3-540-70818-6_14

Gantchev, N., Giannetti, M., \& Li, R. (2019). Does money talk? market discipline through selloffs and boycotts. Market Discipline through Selloffs and Boycotts (July 15, 2020). 
European Corporate Governance Institute-Finance Working Paper(634), 19-9.

Gibson, R., Glossner, S., Krueger, P., Matos, P., \& Steffen, T. (2021). Do responsible investors invest responsibly? Working Paper.

Goodman-Bacon, A. (2018). Difference-in-differences with variation in treatment timing. Working paper.

Gow, I. D., Larcker, D. F., \& Watts, E. M. (2020). Board diversity and shareholder voting. Rock Center for Corporate Governance at Stanford University Working Paper(245).

Hart, O., \& Zingales, L. (2017). Companies should maximize shareholder welfare not market value. Journal of Law, Finance, and Accounting, 2, 247-274.

Hartzmark, S. M., \& Sussman, A. B. (2019). Do investors value sustainability? a natural experiment examining ranking and fund flows. Journal of Finance, 74, 2789-2837.

Heath, D., Macciocchi, D., Michaely, R., \& Ringgenberg, M. C. (2021). Do index funds monitor? The Review of Financial Studies, forthcoming.

Heath, D., Ringgenberg, M. C., Samadi, M., \& Werner, I. M. (2021). Reusing natural experiments. Working Paper.

Kim, S., Kumar, N., Lee, J., \& Oh, J. (2021). Esg lending. Working Paper.

Kim, S. H. (2021). Do mutual fund managers care about star ratings? evidence from portfolio pumping. Working Paper. Retrieved from https://papers.ssrn.com/sol3/ papers.. fm?abstract_id $=3429450$

Krouse, S. (2018). Blackrock: Companies should have at least two female directors. Wall Street Journal, 81-104.

Krueger, P., Sautner, Z., \& Starks, L. T. (2020). The importance of climate risks for institutional investors. The Review of Financial Studies, 33(3), 1067-1111.

Lublin, J., \& Krouse, S. (2017). State street to start voting against companies that don't have women directors. Wall Street Journal. 
Michaely, R., Ordonez-Calafi, G., \& Rubio, S. (2021). Es votes that matter. Working Paper.

Naaraayanan, S. L., Sachdeva, K., \& Sharma, V. (2020). The real effects of environmental activist investing. Available at SSRN 3483692.

Reuter, J., \& Zitzewitz, E. (2021). How much does size erode mutual fund performance? A regression discontinuity approach. Review of Finance.

Riedl, A., \& Smeets, P. (2017). Why do investors hold socially responsible mutual funds? Journal of Finance, 72, 2505-2550.

Romano, J. P., \& Wolf, M. (2005). Stepwise multiple testing as formalized data snooping. Econometrica, 73(4), 1237-1282.

Sautner, Z., van Lent, L., Vilkov, G., \& Zhang, R. (2020). Firm-level climate change exposure. Available at SSRN 3642508.

Sun, L., \& Abraham, S. (2020). Estimating dynamic treatment effects in event studies with heterogeneous treatment effects. Journal of Econometrics.

Teoh, S. H., Welch, I., \& Wazzan, C. P. (2009). The effect of socially activist investment policies on the financial markets: Evidence from the south african boycott. Journal of Business, 72, 35-89. 


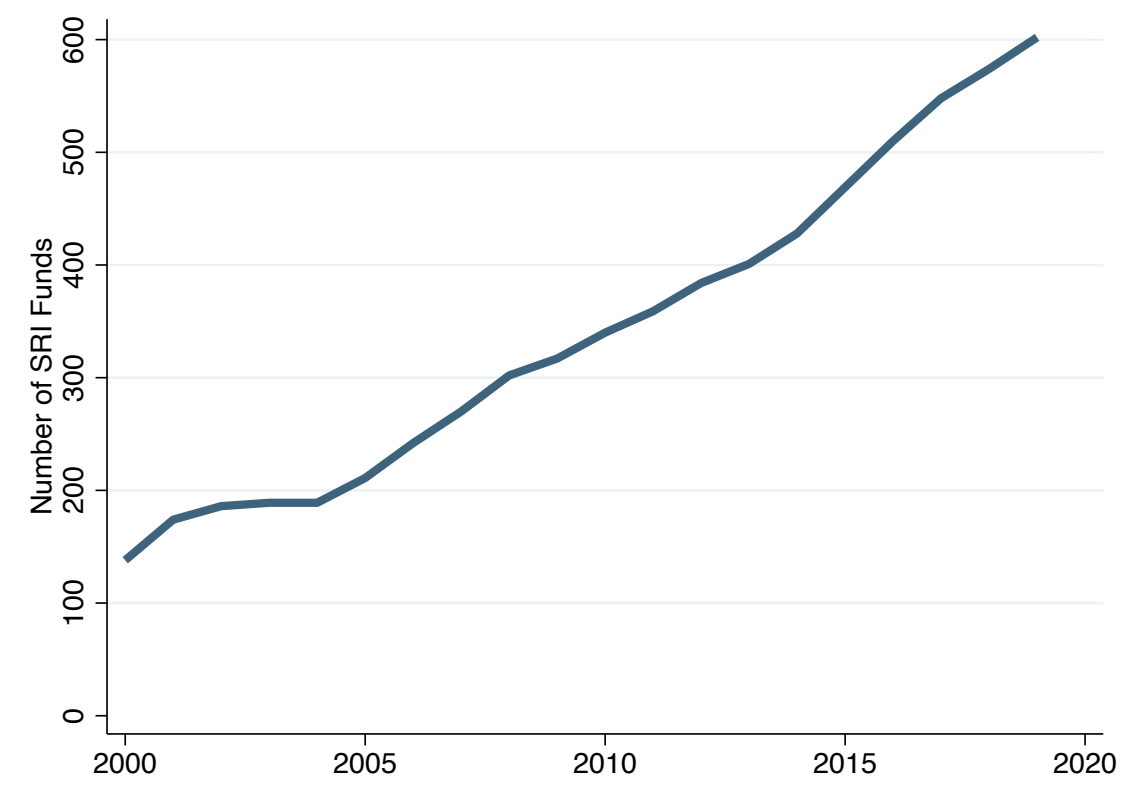

Panel A: Number of SRI funds

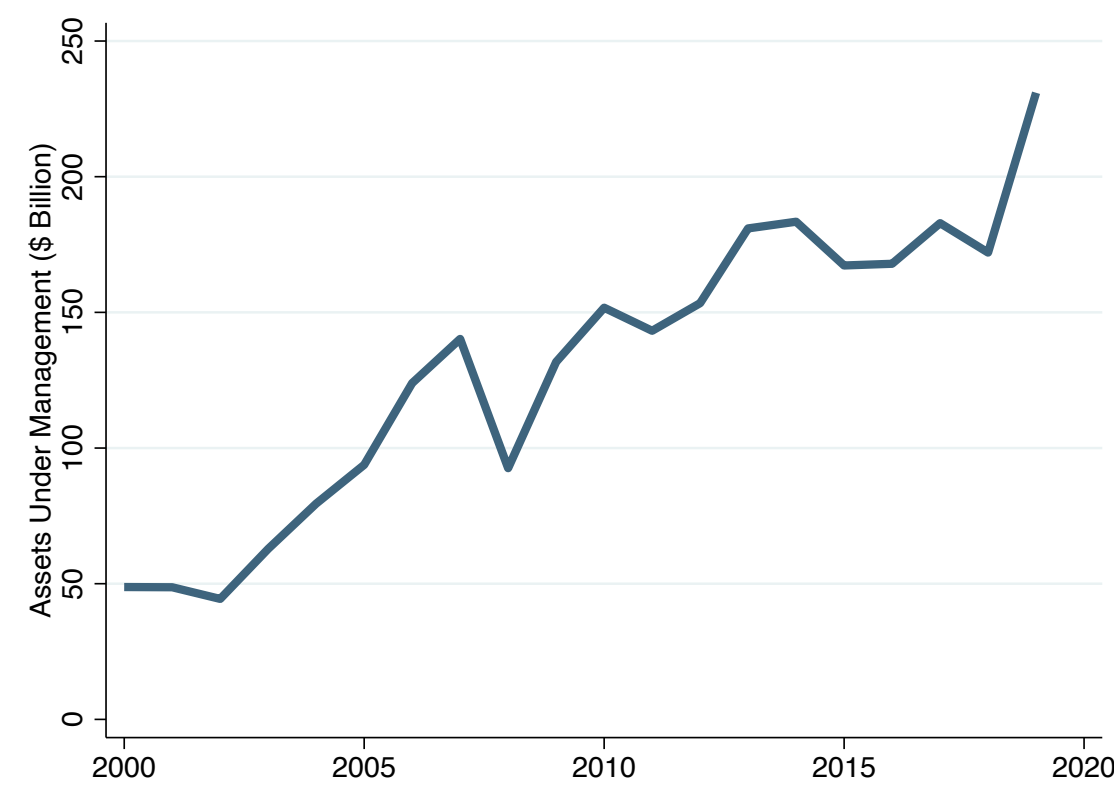

$\underline{\text { Panel B: SRI Assets Under Management }}$

Figure 1. Growth in SRI Funds and Assets over Time

The figure plots the number of SRI funds (Panel A) and the total assets under management in those funds (Panel B) in the CRSP Mutual Fund Database, as of December of each year. 

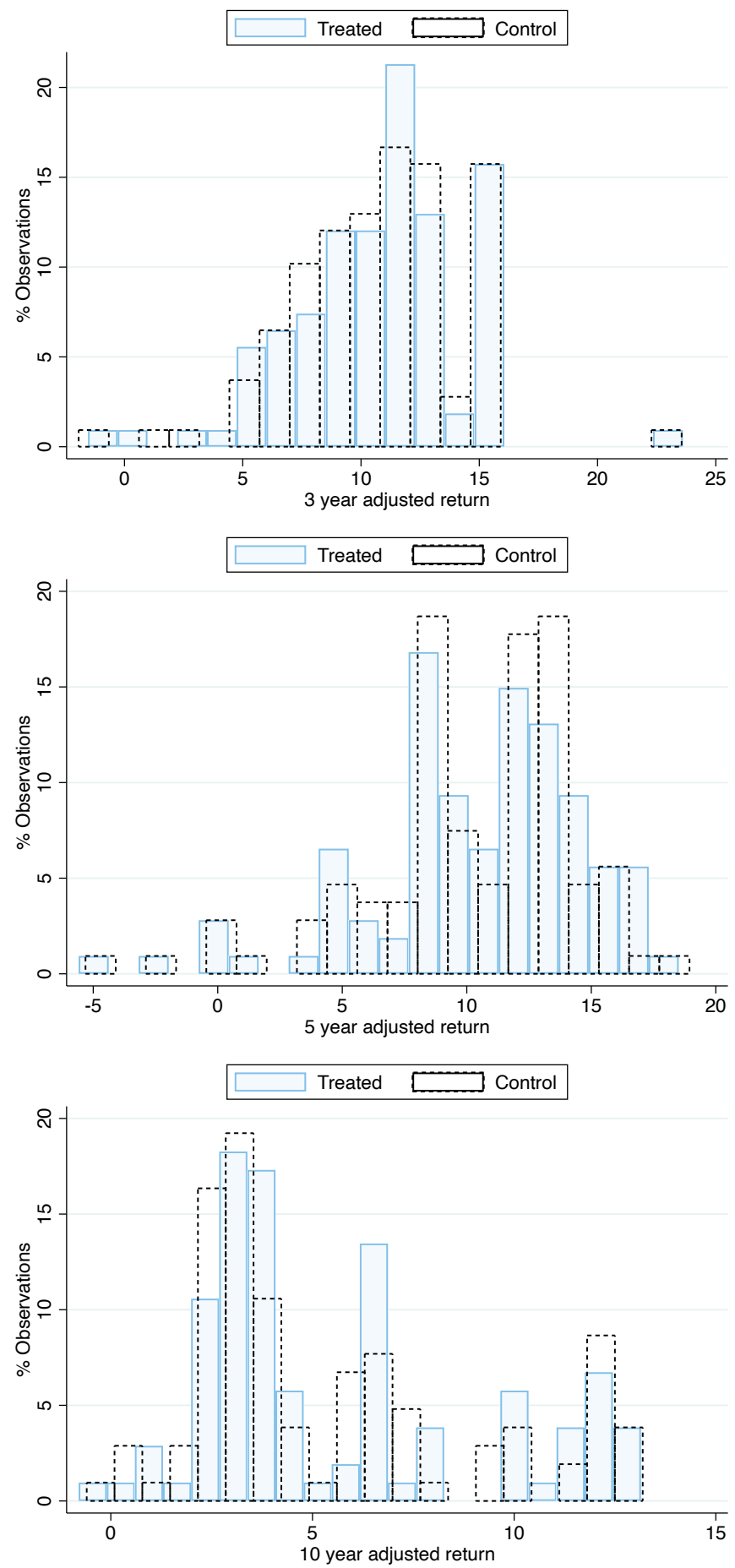

Figure 2. Treated vs. control fund lagged returns

The figure plots the distribution of the variables that determine Morningstar star ratings (3 year, 5 year and 10 year adjusted returns) for the treated and control funds, measured as of the December prior to the treatment year. 


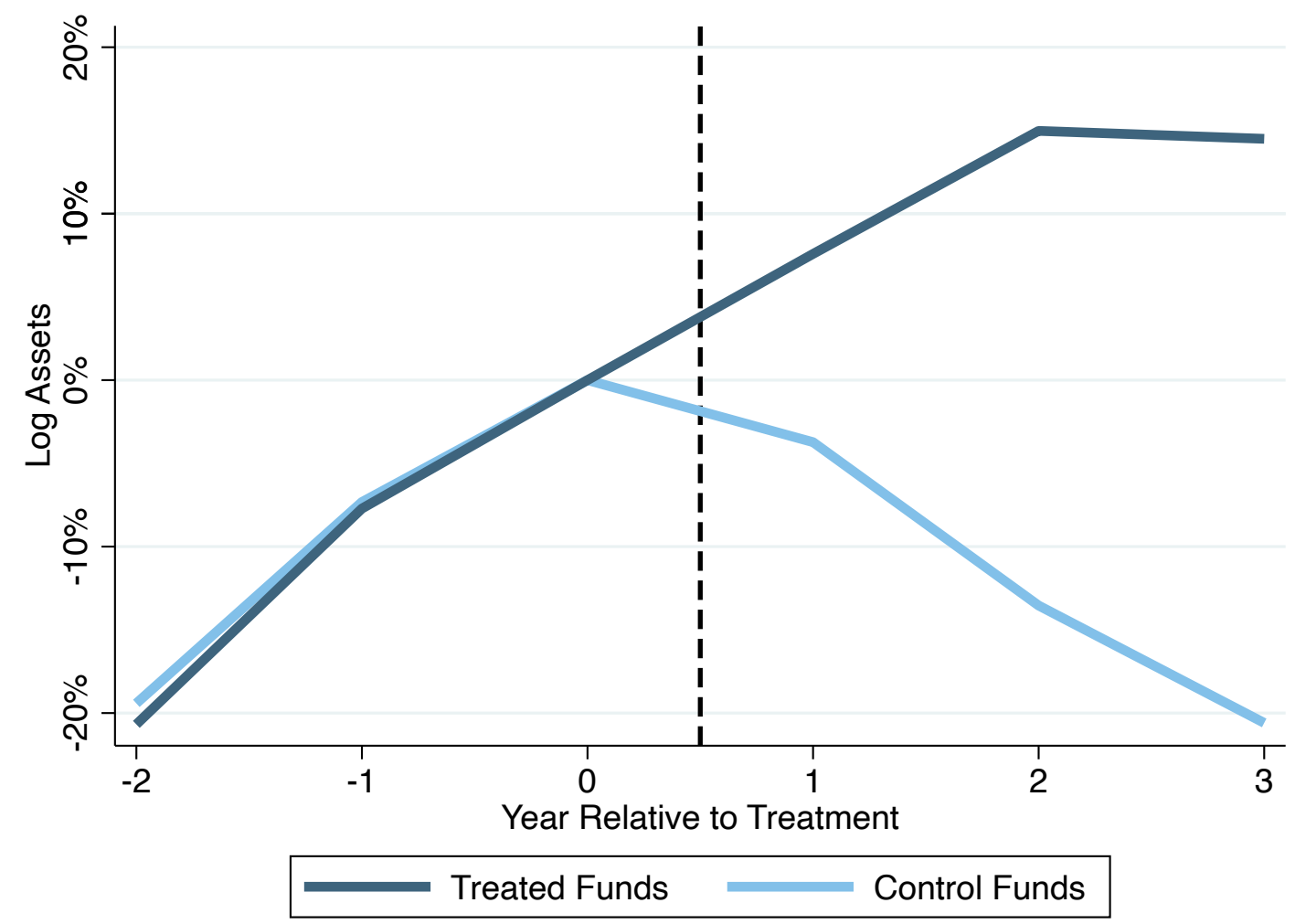

Figure 3. Treated vs. control fund assets, pre- versus post-treatment The figure plots average log fund assets, for treated and control funds separately, in eventtime for three years before and after the cohort year. Both series have been aligned at zero as of the cohort year (year 0, the last pretreatment year) for ease of comparison. 


\section{Table I}

\section{Summary statistics}

The table presents summary statistics for key variables used in our analyses. For each variable, we present the mean, the standard deviation, the 1st decile, the median, and the 10th decile. Definitions and constructions for all variables are in the Appendix Sections A and B.

\begin{tabular}{lccccc}
\hline Variable & $\begin{array}{c}\text { Mean } \\
(1)\end{array}$ & $\begin{array}{c}\text { St. Dev. } \\
(2)\end{array}$ & $\begin{array}{c}\text { p10 } \\
(3)\end{array}$ & $\begin{array}{c}\text { Median } \\
(4)\end{array}$ & $\begin{array}{c}\text { p90 } \\
(5)\end{array}$ \\
\hline SRI Investment (\%) & 0.24 & 0.46 & 0.00 & 0.05 & 0.67 \\
SRI Investment (Active) (\%) & 0.24 & 0.46 & 0.00 & 0.04 & 0.67 \\
SRI Investment (Passive) (\%) & 0.00 & 0.01 & 0.00 & 0.00 & 0.01 \\
Total releases (M pounds) & 1.51 & 5.25 & 0.00 & 0.04 & 3.06 \\
Air (M pounds) & 0.47 & 1.68 & 0.00 & 0.01 & 0.90 \\
Water (M pounds) & 0.13 & 1.11 & 0.00 & 0.00 & 0.05 \\
Land (M pounds) & 0.68 & 4.04 & 0.00 & 0.00 & 0.39 \\
Off-site (M pounds) & 0.22 & 1.09 & 0.00 & 0.00 & 0.33 \\
One-time (thousand pounds) & 4.21 & 41.89 & 0.00 & 0.00 & 0.23 \\
Num_abatements & 3.64 & 15.37 & 0.00 & 0.00 & 8.00 \\
Abatement & 0.43 & 0.49 & 0.00 & 0.00 & 1.00 \\
CCExposure & 1.00 & 2.67 & 0.00 & 0.27 & 1.93 \\
Overall & 3.27 & 0.68 & 2.49 & 3.28 & 4.00 \\
Careeropps & 3.02 & 0.66 & 2.25 & 3.00 & 3.79 \\
Benefits & 3.37 & 0.64 & 2.59 & 3.40 & 4.11 \\
Srleader & 2.92 & 0.73 & 2.03 & 2.91 & 3.83 \\
Worklife & 3.30 & 0.68 & 2.50 & 3.32 & 4.04 \\
Culture & 3.22 & 0.75 & 2.33 & 3.24 & 4.07 \\
Recfrd & 0.58 & 0.25 & 0.26 & 0.59 & 0.92 \\
CEO & 0.29 & 0.41 & -0.19 & 0.32 & 0.82 \\
Outlook & 0.24 & 0.41 & -0.25 & 0.25 & 0.75 \\
Hospitalization & 1.86 & 2.63 & 0.00 & 1.00 & 4.00 \\
Amputation & 0.52 & 1.05 & 0.00 & 0.00 & 1.00 \\
Gender_div & 0.16 & 0.11 & 0.00 & 0.14 & 0.30 \\
Racial_div & 0.11 & 0.12 & 0.00 & 0.10 & 0.25 \\
\hline & & & & &
\end{tabular}




\section{Table II}

\section{Difference-in-differences regression of fund assets}

The table presents results for the effects of the Morningstar star ratings on fund assets. Specifically, we estimate regressions of the form:

$$
y_{i, t}=\beta(\text { Treated } \times \text { Post })+F E_{i}+F E_{t}+\epsilon_{i, t},
$$

Treated is an indicator that equals one for treated funds, and zero otherwise. Treated funds are SRI funds that have a Morningstar star rating that is one star higher than the matched control fund in January of the treatment year. Post is an indicator that equals one after treatment, and zero otherwise, $F E_{i}$ is a fund fixed effect, and $F E_{t}$ is a year fixed effect. Placebo is an indicator that equals one for treated funds in our placebo test, for which treatment funds are defined as SRI funds that have a Morningstar star rating equal to the matched control fund in January of the treatment year. Robust standard errors, clustered at the fund level, are shown in parenthesis. * **, and *** indicate significance at the $10 \%$, $5 \%$, and $1 \%$ levels, respectively.

\begin{tabular}{lccc}
\hline & $\begin{array}{c}\log (\mathrm{AUM}) \\
(1)\end{array}$ & $\begin{array}{c}\text { Falsification } \\
\log (\mathrm{AUM}) \\
(2)\end{array}$ & $\begin{array}{c}\text { Residualized } \\
\log (\mathrm{AUM}) \\
(3)\end{array}$ \\
\hline Treated $\times$ Post & $\begin{array}{c}0.229^{* * *} \\
(0.072)\end{array}$ & & $\begin{array}{c}0.213^{* * *} \\
(0.064)\end{array}$ \\
Placebo $\times$ Post & & 0.008 & \\
& & $(0.059)$ & \\
Observations & 1,161 & 1,778 & 1,088 \\
Adjusted R-squared & 0.909 & 0.918 & 0.923 \\
Fund $\times$ Cohort FE & Yes & Yes & Yes \\
Year FE & Yes & Yes & Yes \\
\hline
\end{tabular}




\section{Table III}

\section{Selection Effects: SRI funds and corporate environmental behavior}

The table presents estimates of the relation between SRI fund investment and firm total pollution (Total releases), air pollution (Air), water pollution (Water), land pollution (Land), total off-site pollution (Off-site), one time pollution (One-time), investments in pollution abatement (Abatement and logAbatements), and climate change exposure (CCExposure). SRI Investment is the percentage of a firm's ownership held by SRI funds (to facilitate the interpretation of the results, the measure is standardized). Definitions for all variables are in the Appendix Section B. Robust standard errors, clustered at the firm level, are shown in parenthesis. *, **, and *** indicate significance at the $10 \%, 5 \%$, and $1 \%$ levels, respectively.

\begin{tabular}{|c|c|c|c|c|c|c|c|c|c|}
\hline & $\begin{array}{c}\text { Total releases } \\
(1)\end{array}$ & $\begin{array}{l}\text { Air } \\
(2)\end{array}$ & $\begin{array}{c}\text { Water } \\
(3)\end{array}$ & $\begin{array}{l}\text { Land } \\
(4)\end{array}$ & $\begin{array}{l}\text { Off-site } \\
(5)\end{array}$ & $\begin{array}{l}\text { One-Time } \\
(6)\end{array}$ & $\begin{array}{c}\text { Abatement } \\
(7)\end{array}$ & $\begin{array}{c}\text { logAbatements } \\
(8)\end{array}$ & $\begin{array}{c}\text { CCExposure } \\
(9)\end{array}$ \\
\hline SRI Investment & $\begin{array}{l}-0.188 \\
(0.060)\end{array}$ & $\begin{array}{l}-0.172 \\
(0.049)\end{array}$ & $\begin{array}{l}-0.084 \\
(0.021)\end{array}$ & $\begin{array}{l}-0.100 \\
(0.055)\end{array}$ & $\begin{array}{l}-0.071 \\
(0.039)\end{array}$ & $\begin{array}{l}-0.018 \\
(0.007)\end{array}$ & $\begin{array}{c}0.022 \\
(0.012)\end{array}$ & $\begin{array}{c}0.045 \\
(0.025)\end{array}$ & $\begin{array}{l}-0.061 \\
(0.023)\end{array}$ \\
\hline $\begin{array}{l}\text { Unadjusted } p \\
\text { Romano-Wolf } p\end{array}$ & $\begin{array}{c}0.002^{* * *} \\
0.040^{* *}\end{array}$ & $\begin{array}{c}0.001^{* * *} \\
0.011^{* *}\end{array}$ & $\begin{array}{l}0.001^{* * *} \\
0.003^{* * *}\end{array}$ & $\begin{array}{c}0.071^{*} \\
0.486\end{array}$ & $\begin{array}{c}0.071^{*} \\
0.486\end{array}$ & $\begin{array}{c}0.008^{* * *} \\
0.109\end{array}$ & $\begin{array}{c}0.067^{*} \\
0.486\end{array}$ & $\begin{array}{c}0.077^{*} \\
0.486\end{array}$ & $\begin{array}{c}0.009^{* * *} \\
0.111\end{array}$ \\
\hline Observations & 4,171 & 4,171 & 4,171 & 4,171 & 4,171 & 4,171 & 3,579 & 3,579 & 15,004 \\
\hline Adjusted R-squared & 0.008 & 0.011 & 0.007 & 0.003 & 0.001 & 0.001 & 0.015 & 0.018 & 0.002 \\
\hline Year FE & Yes & Yes & Yes & Yes & Yes & Yes & Yes & Yes & Yes \\
\hline
\end{tabular}




\section{Table IV}

Selection Effects: SRI funds, employee welfare, and board diversity

The table presents estimates of the relation between SRI fund investment and a firm's employee welfare using data provided by Glassdoor, Inc. and OSHA (Panel A), and board gender and racial diversity (Panel B). SRI Investment is the percentage of a firm's ownership held by SRI funds (to facilitate the interpretation of the results, the measure is standardized). Definitions for all variables are in the Appendix Section B. Robust standard errors, clustered at the firm level, are shown in parenthesis. * **, and *** indicate significance at the $10 \%, 5 \%$, and $1 \%$ levels, respectively.

Panel A: Employee welfare

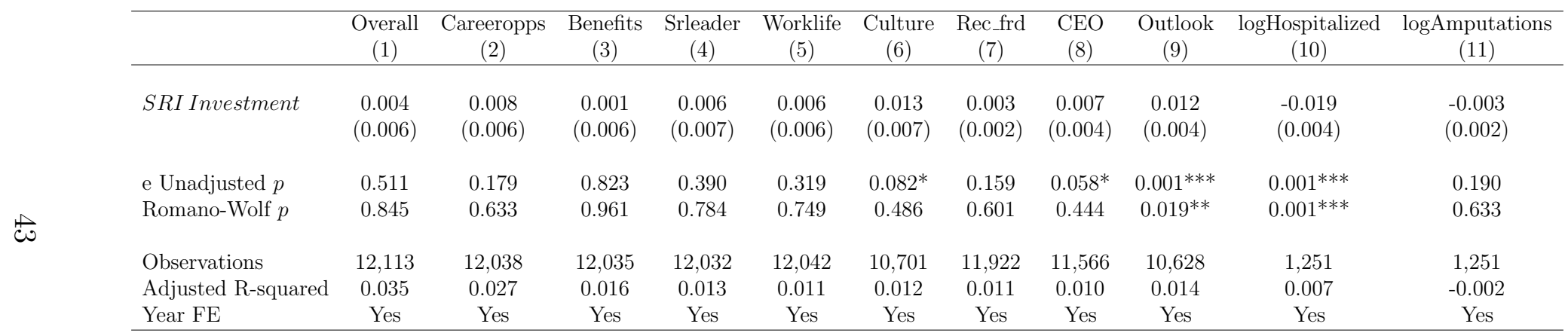

Panel B: Board diversity

\begin{tabular}{lcc}
\hline & $\begin{array}{c}\text { Gender_div } \\
(1)\end{array}$ & $\begin{array}{c}\text { Racial_div } \\
(2)\end{array}$ \\
\hline SRI Investment & 0.006 & 0.000 \\
& $(0.001)$ & $(0.002)$ \\
& & \\
Unadjusted $p$ & $0.001^{* * *}$ & 0.997 \\
Romano-Wolf $p$ & $0.003^{* * *}$ & 0.999 \\
& & \\
Observations & 15,624 & 9,870 \\
Adjusted R-squared & 0.115 & 0.005 \\
Year FE & Yes & Yes \\
\hline
\end{tabular}


Table V

Treatment effects: SRI funds and corporate environmental behavior

The table presents estimates of the effect of SRI fund investment on firm total pollution (Total releases), air pollution (Air), water pollution (Water), land pollution (Land), total off-site pollution (Off-site), one time pollution (One-time), investments in pollution abatement (Abatement and logAbatements), and climate change

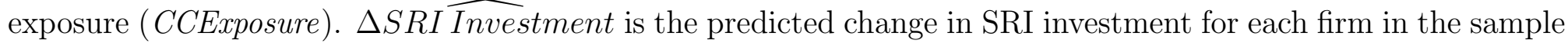
from our paired fund-level difference-in-differences regression (to facilitate the interpretation of the results, the measure is standardized). MDES is the minimum detectable effect size (Bloom, 1995). Definitions for all variables are in the Appendix Section B. Robust standard errors, clustered at the firm level, are shown in parenthesis. *, $* *$, and $* * *$ indicate significance at the $10 \%, 5 \%$, and $1 \%$ levels, respectively.

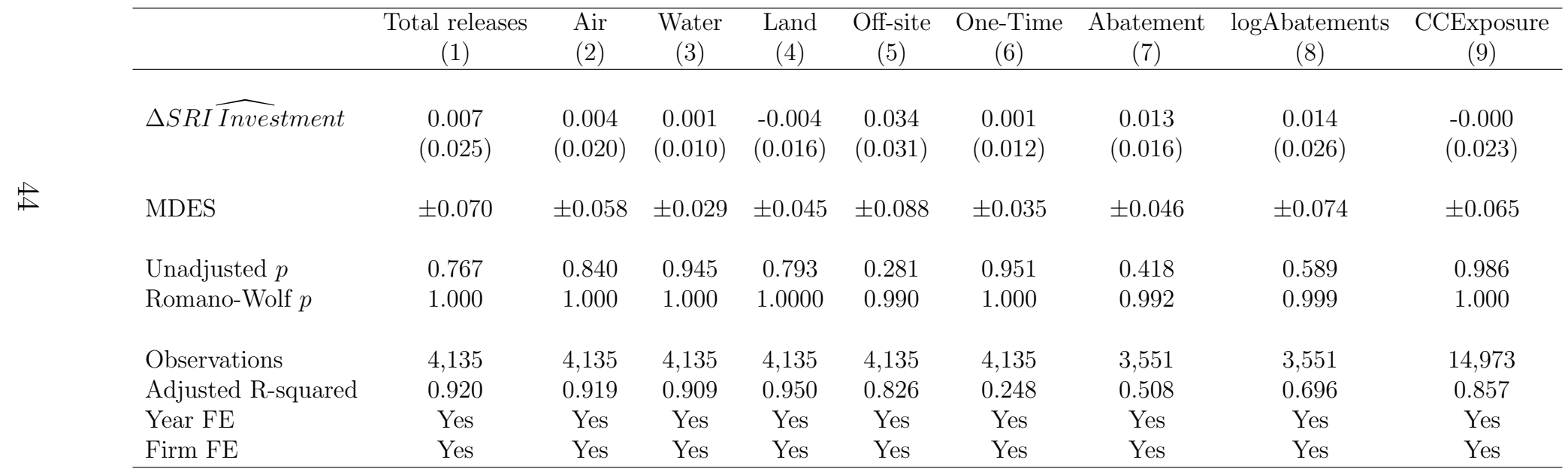




\section{Table VI}

\section{Treatment effects: SRI funds and employee welfare and board diversity}

The table presents estimates of the effect of SRI fund investment on a firm's employee welfare using data provided by Glassdoor, Inc. and OSHA (Panel A), and the effect of SRI fund investment on board diversity (Panel B). $\Delta S R$ Investment is the predicted change in SRI investment for each firm in the sample from our paired fund-level difference-in-differences regression (to facilitate the interpretation of the results, the measure is standardized). MDES is the minimum detectable effect size (Bloom, 1995). Definitions for all variables are in the Appendix Section B. Robust standard errors, clustered at the firm level, are shown in parenthesis. *, **, and *** indicate significance at the $10 \%, 5 \%$, and $1 \%$ levels, respectively.

\section{Panel A: Employee Welfare}

\begin{tabular}{|c|c|c|c|c|c|c|c|c|c|c|c|}
\hline & $\begin{array}{l}\text { Overall } \\
(1)\end{array}$ & $\begin{array}{l}\text { Careeropps } \\
(2)\end{array}$ & $\begin{array}{l}\text { Benefits } \\
(3)\end{array}$ & $\begin{array}{l}\text { Srleader } \\
(4)\end{array}$ & $\begin{array}{c}\text { Worklife } \\
(5)\end{array}$ & $\begin{array}{c}\text { Culture } \\
(6)\end{array}$ & $\begin{array}{l}\text { Rec_frd } \\
(7)\end{array}$ & $\begin{array}{c}\text { CEO } \\
(8)\end{array}$ & $\begin{array}{l}\text { Outlook } \\
\text { (9) }\end{array}$ & $\begin{array}{c}\log \text { Hospitalized } \\
(10)\end{array}$ & $\begin{array}{c}\log \text { Amputation } \\
\text { (11) }\end{array}$ \\
\hline$\Delta S R I \widehat{\text { Investment }}$ & $\begin{array}{l}0.015 \\
(0.011)\end{array}$ & $\begin{array}{l}0.020 \\
(0.011)\end{array}$ & $\begin{array}{c}0.013 \\
(0.009)\end{array}$ & $\begin{array}{l}0.011 \\
(0.011)\end{array}$ & $\begin{array}{c}0.010 \\
(0.010)\end{array}$ & $\begin{array}{l}0.016 \\
(0.013)\end{array}$ & $\begin{array}{c}0.002 \\
(0.004)\end{array}$ & $\begin{array}{c}0.014 \\
(0.006)\end{array}$ & $\begin{array}{c}0.014 \\
(0.008)\end{array}$ & $\begin{array}{c}0.016 \\
(0.009)\end{array}$ & $\begin{array}{l}-0.005 \\
(0.007)\end{array}$ \\
\hline MDES & \pm 0.030 & \pm 0.030 & \pm 0.024 & \pm 0.032 & \pm 0.028 & \pm 0.035 & \pm 0.012 & \pm 0.017 & \pm 0.024 & \pm 0.025 & \pm 0.019 \\
\hline Unadjusted $p$ & 0.149 & $0.070^{*}$ & 0.143 & 0.333 & 0.303 & 0.195 & 0.617 & $0.025^{* *}$ & $0.087^{*}$ & $0.071^{*}$ & 0.494 \\
\hline Romano-Wolf $p$ & 0.859 & 0.692 & 0.859 & 0.984 & 0.984 & 0.918 & 1.000 & 0.404 & 0.727 & 0.692 & 0.996 \\
\hline Observations & 12,017 & 11,939 & 11,938 & 11,933 & 11,944 & 10,592 & 11,820 & 11,451 & 10,512 & 963 & 963 \\
\hline Adjusted R-squared & 0.364 & 0.330 & 0.476 & 0.333 & 0.371 & 0.401 & 0.310 & 0.343 & 0.338 & 0.770 & 0.055 \\
\hline Year FE & Yes & Yes & Yes & Yes & Yes & Yes & Yes & Yes & Yes & Yes & Yes \\
\hline Firm FE & Yes & Yes & Yes & Yes & Yes & Yes & Yes & Yes & Yes & Yes & Yes \\
\hline
\end{tabular}

Panel B: Board Diversity

\begin{tabular}{lcc}
\hline & $\begin{array}{c}\text { Gender_div } \\
(1)\end{array}$ & $\begin{array}{c}\text { Racial_div } \\
(2)\end{array}$ \\
\hline & & \\
$\Delta S R I \widehat{\text { Investment }}$ & 0.005 & 0.002 \\
& $(0.001)$ & $(0.002)$ \\
& & \\
MDES & \pm 0.004 & \pm 0.004 \\
& & \\
Unadjusted $p$ & $0.002^{* * *}$ & 0.295 \\
Romano-Wolf $p$ & 0.105 & 0.984 \\
& & \\
Observations & 15,610 & 9,779 \\
Adjusted R-squared & 0.773 & 0.773 \\
Year FE & Yes & Yes \\
Firm FE & Yes & Yes \\
\hline
\end{tabular}


Table VII

Evidence of Heterogeneity in Treatment Effects

The table presents estimates of the heterogeneity of the effect of SRI funds investment on firm's environmental and social behavior. In Panel A, we interact the fitted values

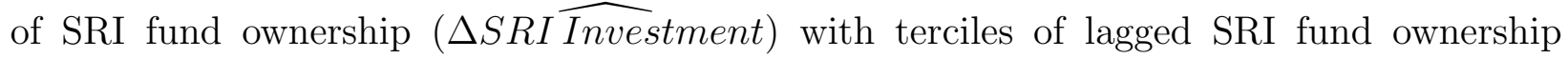
$\left(S R I\right.$ Investment $\left._{t-1}\right)$. In Panel $\mathrm{B}$, we interact the fitted values of SRI fund ownership

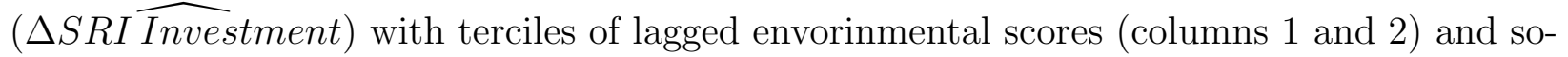
cial scores (column 3 and 4). Robust standard errors, clustered at the firm level, are shown in parenthesis. $*$, **, and $* * *$ indicate significance at the $10 \%, 5 \%$, and $1 \%$ levels, respectively.

Panel A: Heterogeneity by pretreatment SRI fund holdings

\begin{tabular}{|c|c|c|c|c|}
\hline & $\begin{array}{c}\text { Total Releases } \\
\text { (1) }\end{array}$ & $\begin{array}{c}\text { logAbatements } \\
(2)\end{array}$ & $\begin{array}{l}\text { Overall } \\
(3)\end{array}$ & $\begin{array}{c}\text { Gender_div } \\
(4)\end{array}$ \\
\hline $\begin{array}{l}\text { Low SRI Investment } t_{t-1} \\
\times \Delta S R I \widehat{\text { Investment }}\end{array}$ & $\begin{array}{l}-0.003 \\
(0.044)\end{array}$ & $\begin{array}{l}-0.031 \\
(0.038)\end{array}$ & $\begin{array}{l}0.029 * \\
(0.017)\end{array}$ & $\begin{array}{c}0.001 \\
(0.002)\end{array}$ \\
\hline $\begin{array}{l}\text { Mid SRI Investment } \text { In-1 }_{t} \\
\times \Delta S R I \widehat{\text { Investment }}\end{array}$ & $\begin{array}{l}-0.012 \\
(0.042)\end{array}$ & $\begin{array}{c}0.064 \\
(0.040)\end{array}$ & $\begin{array}{l}0.033^{* *} \\
(0.014)\end{array}$ & $\begin{array}{c}0.003 \\
(0.002)\end{array}$ \\
\hline $\begin{array}{l}\text { High SRI Investment }{ }_{t-1} \\
\times \Delta \text { SRI } \text { Investment }^{\text {Inveris }}\end{array}$ & $\begin{array}{c}0.019 \\
(0.026)\end{array}$ & $\begin{array}{l}-0.004 \\
(0.028)\end{array}$ & $\begin{array}{l}0.024^{*} \\
(0.013)\end{array}$ & $\begin{array}{c}0.004^{* * *} \\
(0.002)\end{array}$ \\
\hline F-stat $[$ High $=$ Low $]$ & 0.48 & 0.12 & 0.24 & 2.19 \\
\hline $\begin{array}{l}\text { Observations } \\
\text { Adjusted R-squared } \\
\text { Year FE } \\
\text { Firm FE }\end{array}$ & $\begin{array}{c}3,576 \\
0.923 \\
\text { Yes } \\
\text { Yes }\end{array}$ & $\begin{array}{c}3,197 \\
0.705 \\
\text { Yes } \\
\text { Yes }\end{array}$ & $\begin{array}{c}10,588 \\
0.380 \\
\text { Yes } \\
\text { Yes }\end{array}$ & $\begin{array}{c}13,307 \\
0.781 \\
\text { Yes } \\
\text { Yes }\end{array}$ \\
\hline
\end{tabular}

Panel B: Heterogeneity by pretreatment E\&S Score

\begin{tabular}{|c|c|c|c|c|}
\hline & $\begin{array}{c}\text { Total Releases } \\
\text { (1) }\end{array}$ & $\begin{array}{c}\text { logAbatements } \\
(2)\end{array}$ & $\begin{array}{c}\text { Overall } \\
(3)\end{array}$ & $\begin{array}{c}\text { Gender_div } \\
(4)\end{array}$ \\
\hline $\begin{array}{l}\text { Low E\&S } \text { Score }_{t-1} \\
\times \Delta S R I \widehat{\text { Investment }}\end{array}$ & $\begin{array}{c}0.002 \\
(0.037)\end{array}$ & $\begin{array}{c}0.025 \\
(0.033)\end{array}$ & $\begin{array}{c}0.024 \\
(0.016)\end{array}$ & $\begin{array}{l}0.003^{*} \\
(0.002)\end{array}$ \\
\hline $\begin{array}{l}\text { Mid E\&S } \text { Score }_{t-1} \\
\times \Delta S R I \widehat{\text { Investment }}\end{array}$ & $\begin{array}{c}0.048 \\
(0.151)\end{array}$ & $\begin{array}{c}0.207 \\
(0.134)\end{array}$ & $\begin{array}{c}0.045^{* *} \\
(0.018)\end{array}$ & $\begin{array}{c}0.003 \\
(0.002)\end{array}$ \\
\hline $\begin{array}{l}\text { High E\&S } \text { Score }_{t-1} \\
\times \Delta S R I \widehat{\text { Investment }}\end{array}$ & $\begin{array}{l}-0.009 \\
(0.023)\end{array}$ & $\begin{array}{c}0.015 \\
(0.033)\end{array}$ & $\begin{array}{c}0.036^{* * *} \\
(0.012)\end{array}$ & $\begin{array}{c}0.005^{* * *} \\
(0.002)\end{array}$ \\
\hline F-stat $[$ High $=$ Low $]$ & 0.12 & 0.08 & 0.85 & 1.52 \\
\hline $\begin{array}{l}\text { Observations } \\
\text { Adjusted R-squared } \\
\text { Year FE } \\
\text { Firm FE }\end{array}$ & $\begin{array}{c}2,966 \\
0.926 \\
\text { Yes } \\
\text { Yes }\end{array}$ & $\begin{array}{l}2,605 \\
0.715 \\
\text { Yes } \\
\text { Yes }\end{array}$ & $\begin{array}{c}8,317 \\
0.401 \\
\text { Yes } \\
\text { Yes }\end{array}$ & $\begin{array}{c}10,793 \\
0.779 \\
\text { Yes } \\
\text { Yes }\end{array}$ \\
\hline
\end{tabular}




\section{Appendix}

\section{A. Detailed Data Description}

We aim to examine environmental and social corporate practices. Hence, we collect firm-year level data from various databases. To examine environmental behavior, from the Environmental Protection Agency (EPA) we obtain data from (1) the Form R of the Toxic Release Inventory (TRI database) and (2) from the EPA Pollution Prevention (P2) database. The EPA TRI database contains facility-year level data on the chemical emissions of firms operating in regulated industries that meet a requirement on the minimum number of employees. Facilities in the U.S. are required to report to the EPA the pounds of chemical (grams for dioxin and dioxin-like compounds) released on-site, which are comprised by releases into the ground, air, water, and the total amount of releases transferred off-site.

We use the TRI database to create six measures of pollution at the parent companyyear level. Our aggregated measure is Total releases, which is the total on-site and off-site releases. On site releases are the total quantity of the toxic chemicals released to air, water and land on-site at the facility. We measure Air, which is the total quantity of the chemical released as air emissions at the reporting facility; Water, which is the total quantity of the chemical released on-site as surface water discharges; an Land, which is the total quantity of the chemical injected on site at the facility to underground injection wells, on-site landfills, surface impoundments, or other. We also measure Off Site, which is the total quantity of the toxic chemical reported as transferred to off-site locations for release or disposal, and One-time, which is the total quantity of the toxic chemical released to the environment or transferred off site due to events not associated with routine production processes.

From the EPA P2 database, we collect information about a facility's yearly investments 
in pollution reducing activities. Investment data is available from 2011 to 2018 and is divided into two categories: (1) the number of activities each facility undertakes in order to reduce pollution-for example operating process modifications, taking actions to prevent spills and leaks, and redesigning products to reduce pollution, etc.; and (2) the number of facilities that implemented pollution reducing activities. From the P2 database we create two measures of a firm's propensity and frequency to invest in pollution reducing activities. logAbatements, which is the $\log$ of the number of abatement actions that a firm discloses in a given year, and Abatement, which is an indicator variable equal to 1 if the firm reports an abatement activity across any category, and 0 otherwise.

The EPA data is at the facility-chemical year level. For each facility, the EPA reports the name of the parent company, which is defined as highest-level corporation that owns at least 50 percent of voting shares. In order to merge the EPA data with our sample of funds and portfolio firms, we first combine all the EPA data at the parent-year level. Second, we combine data from the EPA P2 database with data from the EPA TRI database. Finally, we match the EPA parent name with Compustat firm name and retrieve the company gvkey by conducting a fuzzy match (we remove common suffixes like "Company", "Corp", "Incorporated", "LLC" etc.).

In Table I we report descriptive statistics for the EPA data. We observe that on average firms in our sample release 1.5 million pounds of chemicals per year: 470 thousand pounds into the air, 130 thousand pounds into the water, 680 thousand thousand pounds into the land, 220 thousand pounds off-site, and 4,210 pounds of releases due to non-routine production process. ${ }^{26}$ Furthermore, firms in our sample invest in 3.6 abatement activities every year, on average, which result in 43 percent of our sample firms investing in pollution reduc-

\footnotetext{
${ }^{26}$ In the regression models, to assure comparability across firms and consider scale issues, we scale emissions by the company's annual sales and compute the log of one plus the ratio.
} 
ing activities. Finally, we examine a holistic measure of firms' exposure to climate risk using data from Sautner et al. (2020) (CCExposure). ${ }^{27}$ This measure is based on machine learning algorithm that identifies a firm's annual climate change exposure from earnings conference calls. We observe that our sample mean (1.00) is consistent with Sautner et al. (2020).

We also aim to examine each firm's social behavior. To do so, we use four different data sources with micro-level data about a company's employee satisfaction, workplace safety, and board demographics. ${ }^{28}$

To measure employee satisfaction, we obtain data on employee reviews from Glassdoor, Inc., which is a worldwide leader in providing insights about jobs and companies. ${ }^{29}$ Glassdoor, Inc. collects employee feedback, company ratings and reviews, CEO approval ratings, salary reports, interview reviews and questions, and benefits reviews from a large spectrum of companies worldwide.

From Glassdoor, we obtain nine measures of employees reviews of their companies. First, we obtain six different measures of employee satisfaction that each take on numerical values between 0 (bad) and 5 (good). These ratings are (1) the overall company rating (Overall), which shows a mean of 3.27 for our sample firms; (2) the rating for the career opportunity within a corporation (Careeropps), which has a mean of 3.02, (3) the rating for compensation benefits (Benefits), with a mean of 3.37; (4) the rating for senior leadership (Srleader), with a mean of $2.92 ;(5)$ the rating for the corporation's work-life balance (Worklife), with a mean of 3.30; and (6) the rating for the corporate culture (Culture), with a mean of 3.22. We also obtained an indicator variable $R e c_{-} f r d$, which is equal to one if an employee would recommend her company to a friend, and zero otherwise. Approximately 58 percent of the

\footnotetext{
${ }^{27}$ We thank the authors to make their data publicly available, see https://osf.io/fd6jq/

${ }^{28}$ Similar to the process described above for the EPA data, we aggregate data at the parent company-year level (where necessary) and conduct a fuzzy name match with Compustat.

${ }^{29}$ See www.glassdoor.com.
} 
companies in our sample would be recommended by their employees. Finally, we obtain two variables that range from -1 to 1 : $C E O$, which is the review for the company's CEO (-1 if the employee disapproves, 0 if no opinion, and 1 if she approves); and Outlook, which measures the company outlook (-1 if worse, 0 if same, and 1 if better). These two variables have a mean for the firms in our sample of 0.29 and 0.24 respectively.

From the U.S. Department of Labor, Occupational Safety and Health Administration (OSHA), we obtain data on the workplace safety. Starting in 2015, OSHA requires employers to report all severe work-related injuries, defined as an amputation or in-patient hospitalization. Accordingly, we create two variables. First, we measure Hospitalization, which is the annual number of work-related injuries that required hospitalization. Second, we measure Amputation, which is the annual number of work-related injuries that required amputation. $^{30}$ In Table I, we observe that the firms report an average of 1.86 employees' injuries that require hospitalization, and 0.52 employees' injuries that require amputations each year.

We combine these data with BoardEx, which we use to measure gender diversity on the board of directors. Specifically, we estimate the percentage of women on board (Gender_div), which is the number of women on the board divided by the total number of board members. Next, from Institutional Shareholder Services (ISS) database we retrieve data on the board racial diversity (Racial_div), which is the number of non-caucasian directors divided by the total number of board members. In our sample, firms have on average 16 percent of their board represented by women and 11 percent of their board represented by non-caucasian directors (Table I).

\footnotetext{
${ }^{30}$ In the regression models, to assure comparability across firms and consider scale issues, we scale Hospitalization by the company number of employees (in thousands) and compute the log of one plus the ratio (logHospitalized), and we scale Amputation by the company number of employees (in thousands) and compute the log of one plus the ratio (logAmputation).
} 


\section{B. Variable Definitions}

- SRI investment is the percentage of a firm's ownership held by SRI funds. Data is from Morningstar, Bloomberg and the U.S. Sustainable Investment Forum.

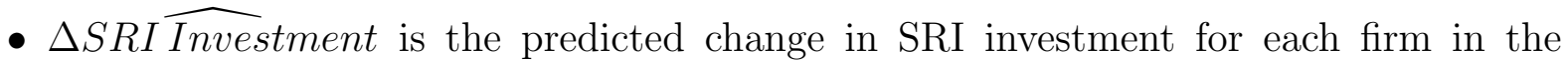
sample from our paired fund-level difference-in-differences regression. Data is from Morningstar, Bloomberg and the U.S. Sustainable Investment Forum.

- Total releases is the total on-site and off-site releases (data in million pounds in Table I). To assure comparability across firms and consider scale issues, in the regression models (Tables III and V) we scale emissions by the company's annual sales and compute the log of one plus the ratio. Data is from the Form R of the EPA Toxic Release Inventory (TRI) database.

- Off-site is the total quantity of the toxic chemical reported as transferred to off-site locations for release or disposal (data in million pounds in Table I). To assure comparability across firms and consider scale issues, in the regression models (Tables III and V) we scale emissions by the company's annual sales and compute the log of one plus the ratio. Data is from the Form $\mathrm{R}$ of the EPA Toxic Release Inventory (TRI) database.

- Air is the total quantity of the chemical released as air emissions at the reporting facility (data in million pounds in Table I). To assure comparability across firms and consider scale issues, in the regression models (Tables III and V) we scale emissions by the company's annual sales and compute the log of one plus the ratio. Data is from the Form R of the EPA Toxic Release Inventory (TRI) database. 
- Water is the total quantity of the chemical released on-site as surface water discharges (data in million pounds in Table I). To assure comparability across firms and consider scale issues, in the regression models (Tables III and V) we scale emissions by the company's annual sales and compute the log of one plus the ratio. Data is from the Form R of the EPA Toxic Release Inventory (TRI) database.

- Land is the total quantity of the chemical injected on site at the facility to underground injection wells, on-site landfills, surface impoundments, or other (data in million pounds in Table I). To assure comparability across firms and consider scale issues, in the regression models (Tables III and V) we scale emissions by the company's annual sales and compute the $\log$ of one plus the ratio. Data is from the Form $\mathrm{R}$ of the EPA Toxic Release Inventory (TRI) database.

- One-time is the total quantity of the toxic chemical released to the environment or transferred off site due to events not associated with routine production processes (data in thousand pounds in Table I). To assure comparability across firms and consider scale issues, in the regression models (Tables III and V) we scale emissions by the company's annual sales and compute the $\log$ of one plus the ratio. Data is from the Form $\mathrm{R}$ of the EPA Toxic Release Inventory (TRI) database.

- Num_abatements is the number of abatement actions (investments in pollution reducing activities) that a firm discloses in a given year. Data from the EPA P2 database.

- logAbatements is the log of one plus the number of abatement actions (investments in pollution reducing activities) that a firm discloses in a given year. Data from the EPA P2 database. 
- Abatement is an indicator variable equal to 1 if the firm reports an abatement activity across any category, and 0 otherwise. Data from the EPA P2 database.

- CCExposure is the relative frequency with which bigrams related to climate change occur in the transcripts of analyst conference calls. We count the number of such bigrams and divide by the total number of bigrams in the transcripts. We average values of the four analyst earnings conference calls during the year and multiply the ratio by 1,000. Data from Sautner et al. (2020).

- Overall is the overall employees' satisfaction score. Data from Glassdoor, Inc.

- Careeropps is the employees' score for career opportunities. Data from Glassdoor, Inc.

- Benefits is the employees' score for compensation benefits. Data from Glassdoor, Inc.

- Srleader is the employees' score for senior leadership. Data from Glassdoor, Inc.

- Worklife is the employees' score for work-life balance. Data from Glassdoor, Inc.

- Culture is the employees' score for corporate culture (i.e., cultural values). Data from Glassdoor, Inc.

- Rec_frd is an indicator variable that takes the value of one if the employee would recommend the company to a friend and zero otherwise. Data from Glassdoor, Inc.

- $C E O$ measures the employees' $\mathrm{CEO}$ approval (-1 if disapprove, 0 if no opinion, and 1 if approve). Data from Glassdoor, Inc.

- Outlook measures the employees' company outlook (-1 if worse, 0 if same, and 1 if better). Data from Glassdoor, Inc. 
- Hospitalization is the number of work-related injuries that required hospitalization. Data from the U.S. Department of Labor, OSHA.

- logHospitalized is the log of one plus the number of work-related injuries that required hospitalization scaled by the number of employees in thousands. Data from the U.S. Department of Labor, OSHA.

- Amputation is the number of work-related injuries that required amputation. Data from the U.S. Department of Labor, OSHA.

- $\log$ Amputation is the $\log$ of one plus the number of work-related injuries that required amputation scaled by the number of employees in thousands. Data from the U.S. Department of Labor, OSHA.

- Gender_div is the ratio of women directors on the board. Data from BoardEx.

- Racial_div is the ratio of the number of non-caucasian directors on the board. Data from ISS. 


\section{Tests of match quality and conditional independence}

This section presents additional tests of the hypothesis that our matched treated and control funds were indistinguishable ex ante on all characteristics except their Morningstar star rating.

Table A1 Panel A shows the comparison between the treated and control fund-cohortyears, measured as of December just prior to treatment. The first row illustrates the main idea behind our research design: Treated funds were assigned exactly a one-star higher rating than the matched control funds. Otherwise, as well as belonging to the same Morningstar fund category in each case, the two groups of funds are very closely matched in terms of their size and fundamentals. In particular, the mean differences in the three, five, and ten year Morningstar returns - the inputs that determine the Morningstar star ratings - are 8, 10 and 9 basis points respectively. None of these differences is economically or statistically significant, as is also evident in Figure 2.

Like a regression discontinuity design (RDD), in our setting unconfounded causal inference rests on conditional independence of treatment status. Because the Morningstar star ratings are determined by lagged fund returns, we cannot use fund ratings directly as our treatment variable. Instead, we construct matched pairs of funds near the star-rating thresholds. If the matched pairs are sufficiently similar ex ante, then lagged fund returns should not predict treatment status within the matched sample.

Table A1 Panel B examines this requirement. The first two columns regress the Morningstar star rating of each fund-year on the fund's lagged Morningstar returns using fund category-by-year fixed effects (the groups within which the star ratings are determined). We see that both in the full sample and our matched sample, the lagged Morningstar returns strongly predict a fund's Morningstar star rating, reflected by both their statistical signif- 
icance and the adjusted $\mathrm{R}^{2}$ of the estimates. By comparison, in Column 3, the dependent variable is treatment versus control status within the matched sample. Here, the lagged Morningstar returns have no predictive power. The coefficients on the individual 3,5 and 10 year lagged returns are economically small and statistically insignificant. Moreover, the adjusted $\mathrm{R}^{2}$ of the model is substantially negative. We conclude that our matched funds are similar ex ante on all characteristics including, crucially, the lagged Morningstar returns that determine treatment assignment.

A third test is that if the difference in star ratings between treated and control funds was due only to the arbitrary breakpoints of the Morningstar star function, the funds should satisfy the parallel trends requirement - in the absence of their different star ratings, their AUM would have evolved similarly. To examine how our treated and control funds' assets evolve over time, we take each set of matched funds and examine their assets under management in event time for three years before and after the cohort-year. 


\section{Table A1 \\ Comparison of treated and control funds}

The table presents comparisons of treated versus control funds, measured as of the December prior to the treatment year. In Panel A, for each fund we examine Morningstar stars, fund assets, Morningstar returns, and fund turnover and fees. In Columns (1) and (3) we report the mean for treatment and control funds respectively, in Columns (2) and (4) we report the standard deviation for treatment and control funds respectively, and in Columns (5) and (6) we report the difference in means and the associated t-statistics. In Panel B, we report tests of the conditional independence of treatment status. We regress the Morningstar stars (MS Star Rating on their inputs (3, 5, and 10 years returns, and fund category-year fixed effects) in the whole sample (Column 1), and matched sample (Column 2). In Column (3) we regress the treatment status on the same inputs described above.

Panel A: Two-Sample Comparison

\begin{tabular}{lcccccccc}
\hline \multirow{2}{*}{ Variable } & \multicolumn{2}{c}{ Treated Funds } & & \multicolumn{2}{c}{ Control Funds } & & \\
\cline { 2 - 3 } & Mean & St.Dev. & & Mean & St.Dev. & & Difference & t-stat \\
& $(1)$ & $(2)$ & & $(3)$ & $(4)$ & & $(5)$ & $(6)$ \\
\hline MS Star Rating & 3.88 & 0.65 & & 2.88 & 0.65 & & $1.00^{* * *}$ & $(11.28)$ \\
Fund Assets $(\$ \mathrm{M})$ & 952.45 & 1395.67 & & 894.92 & 1492.70 & 57.53 & $(0.29)$ \\
3 year MS Return & 10.81 & 3.59 & & 10.72 & 3.55 & 0.08 & $(0.17)$ \\
5 year MS Return & 10.35 & 4.34 & & 10.25 & 4.28 & 0.10 & $(0.16)$ \\
10 year MS Return & 5.59 & 3.56 & & 5.50 & 3.56 & 0.09 & $(0.19)$ \\
Turnover Ratio & 0.33 & 0.34 & & 0.43 & 0.82 & & -0.10 & $(-1.13)$ \\
Management Fee & 0.47 & 0.33 & & 0.48 & 0.29 & -0.01 & $(-0.21)$ \\
Expense Ratio & 0.75 & 0.33 & & 0.83 & 0.37 & -0.08 & $(-1.58)$ \\
Observations & 108 & & & 108 & & & \\
\hline
\end{tabular}

Panel B: Testing Conditional Independence

\begin{tabular}{lccc}
\hline & $\begin{array}{c}\text { MS Star Rating } \\
(1)\end{array}$ & $\begin{array}{c}\text { MS Star Rating } \\
(2)\end{array}$ & $\begin{array}{c}\text { Treated } \\
(3)\end{array}$ \\
\hline 3 year MS Return & $0.09^{* * *}$ & $0.16^{* *}$ & 0.01 \\
& $(0.00)$ & $(0.07)$ & $(0.07)$ \\
5 year MS Return & $0.15^{* * *}$ & $0.20^{* * *}$ & 0.01 \\
& $(0.01)$ & $(0.08)$ & $(0.07)$ \\
10 year MS Return & $0.17^{* * *}$ & $0.29^{* * *}$ & 0.06 \\
& $(0.02)$ & $(0.08)$ & $(0.07)$ \\
Funds & & & \\
Observations & All & Matched & Matched \\
Adjusted R-squared & 20,662 & 208 & 208 \\
MS Fund Category $\times$ Year FE & 0.650 & 0.513 & -0.175 \\
\hline
\end{tabular}




\section{Effects on Treated Funds' Holdings}

An important condition of our research design is that SRI funds do not change their portfolio allocation as a result of different star ratings. In particular, did treated funds increase their holdings pro rata, or did they channel the inflows into relatively low-ESG or relatively high-ESG portfolio firms? In this section we examine the effects of exogenous fund flows on treated funds' holdings.

Table A2 investigates the effects of the flow of assets into treated funds on their holdings. Here, the panel is fund by cohort year by portfolio firm. Column 1 regresses post-treatment status for treated funds on an indicator variable for whether a firm held is a new holding, that is, a firm that the fund did not hold at all in the previous year. We see that if anything, treated funds were slightly less likely to add a new firm to their holdings in post-treatment years. Column 2 shows that firms were also very slightly less likely to drop a firm from their holdings in post-treatment years. Thus, the inflows into treated funds were channeled into their existing holdings.

Table A2 Columns 3-5 examine how the investment in individual portfolio firms changed in a different way. Here, the dependent variable is the fraction of the fund's total net assets that each portfolio firm represented. We see that both overall and for high- and low-ESG firms separately, the inflows into treated funds were not accompanied by any change in their weights in the fund portfolio.

Overall, we conclude that the inflows into treated funds due to their higher Morningstar star ratings were, on average, allocated pro rata to the fund's existing portfolio. 


\section{Table A2}

\section{Effects on Treated Funds' Holdings}

The table presents results examining the effects of the Morningstar ratings on fund holdings. Specifically, we estimate regressions of the form:

$$
y_{i, t}=\beta(\text { Treated } \times \text { Post })+F E_{i}+F E_{t}+\epsilon_{i, t},
$$

where Treated is an indicator that equals one for treated funds, and zero otherwise and Post is an indicator that equals one after treatment, and zero otherwise, $F E_{i}$ is a fund fixed effect, and $F E_{t}$ is a year fixed effect. Treated funds are SRI funds that have a Morningstar rating that is one star higher than the matched control fund in January of the treatment year. Robust standard errors, clustered at the fund level, are shown in parenthesis. *, **, and $* * *$ indicate significance at the $10 \%, 5 \%$, and $1 \%$ levels, respectively.

\begin{tabular}{lccccc}
\hline & Added Stock & Dropped Stock & \multicolumn{3}{c}{ \% Total Net Assets } \\
& $(1)$ & $(2)$ & $(3)$ & $(4)$ & $(5)$ \\
\hline Treated $\times$ Post & & & & & \\
& -0.001 & -0.008 & 0.001 & -0.006 & 0.002 \\
& $(0.010)$ & $(0.008)$ & $(0.011)$ & $(0.014)$ & $(0.013)$ \\
Firms & & & & & \\
Observations & All & All & All & High ES & Low ES \\
Adjusted R-squared & $0.023,354$ & 378,354 & 218,941 & 85,724 & 77,366 \\
Fund $\times$ Cohort FE & Yes & 0.029 & 0.437 & 0.381 & 0.568 \\
Year FE & Yes & Yes & Yes & Yes & Yes \\
\hline
\end{tabular}




\section{E. Evidence of Longer-Run Effects}

One concern with our main estimates of the causal effects of SRI fund investment is that we regress the level of firms' E\&S behavior on the predicted, exogenous change in SRI fund investment from the previous year. Firm policies are often slow to change, so it could be that one year is simply not enough time to observe a treatment effect.

In Table A3 we examine firm E\&S behavior at longer horizons, namely two and three years post-treatment. Again, we see zero treatment effects on total pollution releases, investment in pollution abatements, and overall employee ratings of the firm. We also continue to see a positive effect on board gender diversity in year 2 , but the effect is smaller and insignificant by year 3 .

The economic magnitude of the coefficients remains tiny, and the minimum detectable effect size (MDES) suggests that our estimates remain well-powered to detect meaningful

changes in corporate policy. We simply find zero effects over the two- and three-year horizon as well as our baseline one-year horizon. 


\section{Table A3}

\section{Evidence of Longer-Run Effects}

The table presents estimates of the effect of SRI fund investment on firm behavior over longer periods of time

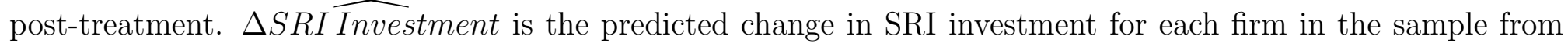
our paired fund-level difference-in-differences regression (to facilitate the interpretation of the results, the measure is standardized). MDES is the minimum detectable effect size (Bloom, 1995). Definitions for all variables are in the Appendix Section B. Robust standard errors, clustered at the firm level, are shown in parenthesis. * **, and *** indicate significance at the $10 \%, 5 \%$, and $1 \%$ levels, respectively.

\begin{tabular}{|c|c|c|c|c|c|c|c|c|}
\hline \multirow[b]{2}{*}{ Relative to treatment year: } & \multicolumn{2}{|c|}{ Total Releases } & \multicolumn{2}{|c|}{ logAbatements } & \multicolumn{2}{|c|}{ Overall } & \multicolumn{2}{|c|}{ Gender_div } \\
\hline & $\begin{array}{c}t+2 \\
(1)\end{array}$ & $\begin{array}{c}t+3 \\
(2)\end{array}$ & $\begin{array}{c}t+2 \\
(3)\end{array}$ & $\begin{array}{c}t+3 \\
(4)\end{array}$ & $\begin{array}{c}t+2 \\
(5)\end{array}$ & $\begin{array}{c}t+3 \\
(6)\end{array}$ & $\begin{array}{c}t+2 \\
(7)\end{array}$ & $\begin{array}{c}t+3 \\
(8)\end{array}$ \\
\hline$\Delta S R I \widehat{\text { Investment }}$ & $\begin{array}{c}0.012 \\
(0.027)\end{array}$ & $\begin{array}{c}0.001 \\
(0.027)\end{array}$ & $\begin{array}{c}0.003 \\
(0.026)\end{array}$ & $\begin{array}{c}-0.001 \\
(0.030)\end{array}$ & $\begin{array}{c}0.008 \\
(0.011)\end{array}$ & $\begin{array}{c}0.003 \\
(0.011)\end{array}$ & $\begin{array}{c}0.003^{* *} \\
(0.001)\end{array}$ & $\begin{array}{c}0.002 \\
(0.002)\end{array}$ \\
\hline MDES & \pm 0.077 & \pm 0.077 & \pm 0.074 & \pm 0.086 & \pm 0.031 & \pm 0.030 & \pm 0.004 & \pm 0.004 \\
\hline Observations & 3,576 & 3,006 & 3,197 & 2,631 & 10,588 & 9,070 & 13,307 & 10,997 \\
\hline Adjusted R-squared & 0.923 & 0.923 & 0.705 & 0.729 & 0.380 & 0.395 & 0.781 & 0.793 \\
\hline Year FE & Yes & Yes & Yes & Yes & Yes & Yes & Yes & Yes \\
\hline Firm FE & Yes & Yes & Yes & Yes & Yes & Yes & Yes & Yes \\
\hline
\end{tabular}




\section{F. Evidence of Dynamic Selection and Catering}

Table A4 shows estimates of the association between lagged changes in firms' E\&S behavior and SRI fund investment. We see that in contrast to our very strong evidence of static selection in the paper - namely, that SRI fund investment is strongly associated with

better E\&S behavior by portfolio firms - there is zero association, precisely estimated, of SRI fund investment with firms' improvement in their E\&S behavior.

Thus, while we cannot rule out the possibility that firms attempt to cater to SRI fund investment with the intention of attracting SRI, the data suggest that such efforts (if they exist) are unsuccessful. 


\section{Table A4}

\section{Evidence of Dynamic Selection and Catering}

The table presents estimates of the dynamic relation between firms' environmental and social behavior and investment by SRI funds. We regress changes in SRI funds ownership ( $\Delta_{t}$ Investment by SRI Funds) on lagged changes in E\&S behavior. Robust standard errors, clustered at the firm level, are shown in parenthesis. ${ }^{*}, * *$, and ${ }^{* * *}$ indicate significance at the $10 \%, 5 \%$, and $1 \%$ levels, respectively.

\begin{tabular}{lcccc}
\hline Dependent Variable: & \multicolumn{4}{c}{$\Delta_{t}$ Investment by SRI Funds } \\
& $(1)$ & $(2)$ & $(3)$ & $(4)$ \\
Independent Variable: & Total Releases & logAbatements & Overall & Gender_div \\
\hline \multirow{2}{*}{$\Delta$ Indep Var $_{t}$} & & & & \\
& -0.00 & -0.00 & $0.00^{*}$ & 0.00 \\
$\Delta$ IndepVar $_{t-1}$ & $(0.00)$ & $(0.00)$ & $(0.00)$ & $(0.00)$ \\
& 0.00 & -0.00 & $0.00^{* *}$ & $0.00^{*}$ \\
& $(0.00)$ & $(0.00)$ & $(0.00)$ & $(0.00)$ \\
Observations & & & & \\
Adjusted R-squared & 2,930 & 2,359 & 7,873 & 10,776 \\
Year FE & -0.090 & -0.121 & -0.077 & -0.103 \\
Firm FE & Yes & Yes & Yes & Yes \\
& Yes & Yes & Yes & Yes \\
\hline
\end{tabular}




\section{G. Heterogeneous Treatment Effects}

A recent set of papers has highlighted potential issues with difference-in-differences estimation, in particular in the presence of heterogeneous treatment effects over time (Sun and Abraham (2020); Goodman-Bacon (2018)). Since the treatment effects of Morningstar ratings on investor flows could plausibly vary over time, we investigate this possibility using the approach of Sun and Abraham (2020).

Figure A1 plots the implicit weighting function of our difference-in-differences estimate for the effect of Morningstar ratings on fund flows. We see that the implicit weights are wellbehaved according to their recommended interpretation. In particular, the weights are of the same sign for all cohorts within each event-time group, with one small exception namely observations 2 years post-treatment for the 2017 cohort. Dropping this cohort from our estimates yields similar results. Thus, there is little concern that heterogeneity in treatment effects may be biasing our estimates. 


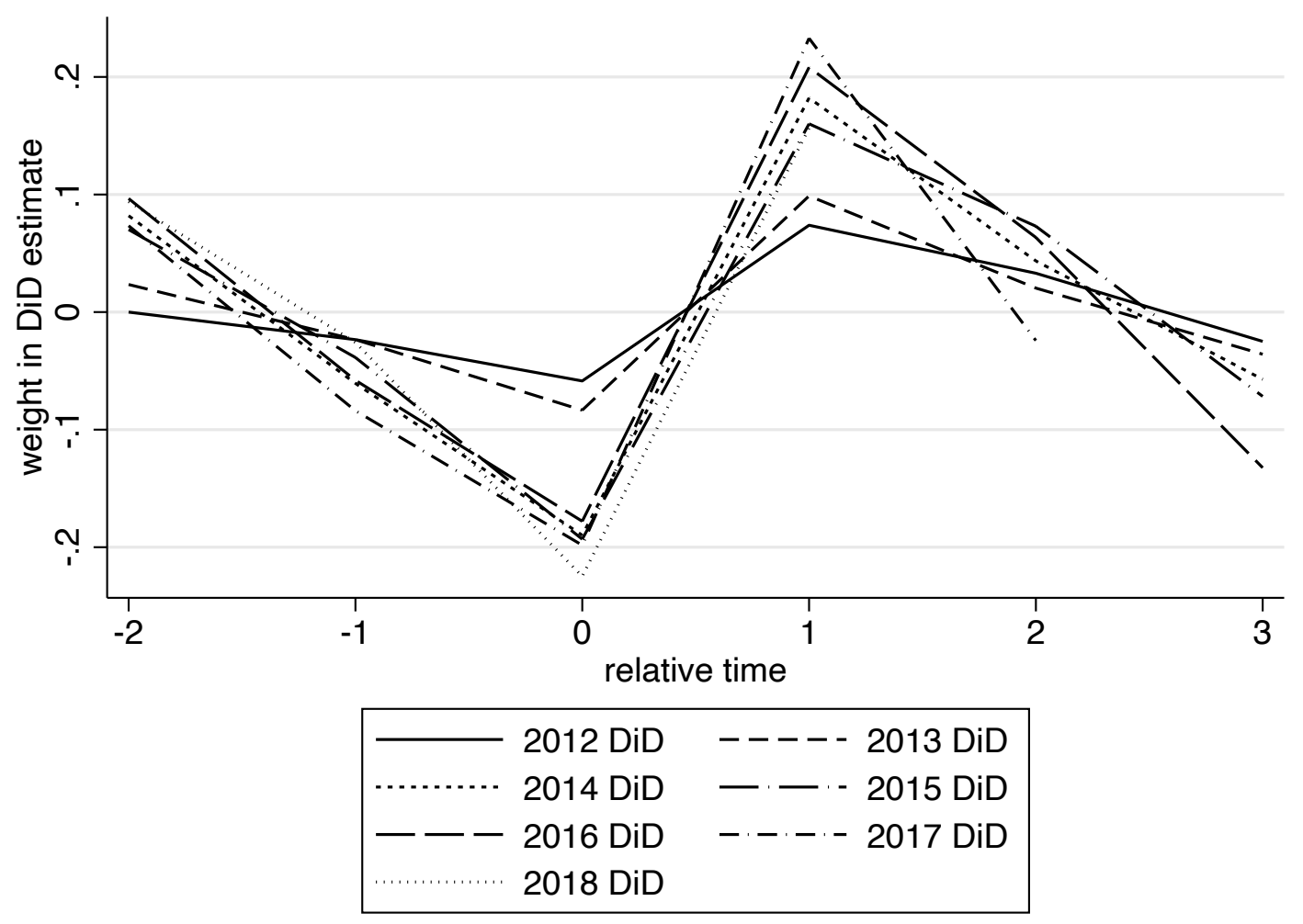

Figure A1. Implicit Weights in the Diff-in-Diff Estimate of Morningstar Star Ratings on Fund AUM

The figure plots the implicit weights estimated by the Sun and Abraham (2020) decomposition of our main difference-in-difference estimator in event time. 